\title{
Signal transduction and information processing in mammalian taste buds
}

\author{
Stephen D. Roper
}

Received: 9 December 2006 / Accepted: 4 January 2007 / Published online: 28 April 2007

(C) Springer-Verlag 2007

\begin{abstract}
The molecular machinery for chemosensory transduction in taste buds has received considerable attention within the last decade. Consequently, we now know a great deal about sweet, bitter, and umami taste mechanisms and are gaining ground rapidly on salty and sour transduction. Sweet, bitter, and umami tastes are transduced by G-protein-coupled receptors. Salty taste may be transduced by epithelial $\mathrm{Na}$ channels similar to those found in renal tissues. Sour transduction appears to be initiated by intracellular acidification acting on acidsensitive membrane proteins. Once a taste signal is generated in a taste cell, the subsequent steps involve secretion of neurotransmitters, including ATP and serotonin. It is now recognized that the cells responding to sweet, bitter, and umami taste stimuli do not possess synapses and instead secrete the neurotransmitter ATP via a novel mechanism not involving conventional vesicular exocytosis. ATP is believed to excite primary sensory afferent fibers that convey gustatory signals to the brain. In contrast, taste cells that do have synapses release serotonin in response to gustatory stimulation. The postsynaptic targets of serotonin have not yet been identified. Finally, ATP secreted from receptor cells also acts on neighboring taste cells to stimulate their release of serotonin. This suggests that there is important information processing and signal coding taking place in the mammalian taste bud after gustatory stimulation.
\end{abstract}

S. D. Roper $(\bowtie)$

Department of Physiology and Biophysics,

Miller School of Medicine, University of Miami,

Miami, FL 33136, USA

e-mail: roper@miami.edu
Keywords Taste bud - Transduction · ATP S Serotonin . Neurotransmitters $\cdot$ Sweet $\cdot$ Bitter $\cdot$ Umami $\cdot$ Salty $\cdot$ Sour

\section{Introduction}

This review discusses two of the more intriguing aspects of sensory mechanisms in taste, (a) signal transduction, including a brief description of the ligands, their receptors, and the early events in taste transduction, and (b) signal processing within the taste bud, including an overview of how gustatory information is encoded by the taste bud. I refer the reader to a number of excellent recent reviews that also cover these topics and features of central processing in gustation [1-4].

Signal transduction is discussed first. This topic includes interactions of ligands with ion channels and $G$ proteincoupled taste receptors (GPCRs) and, for the latter, downstream intracellular second-messenger cascades. The current consensus is that there are five basic tastes - sour, salty, sweet, bitter, and umami. For sour and salty tastes, the initial transduction events are only incompletely understood, although they are the focus of intense investigation. For sweet, bitter, and umami tastes, considerable information has accumulated in the past few years. Other qualities such as fatty may also be basic tastes with their own unique signal-transduction pathways $[5,6]$, but this remains to be widely accepted.

After a discussion of transduction, I will analyze signal processing. The generation of intracellular signals within taste receptor cells leads to an important flow of information within taste buds. This information processing involves cell-cell communication and excitatory synaptic activation of primary sensory afferents, the latter of which ultimately 
carry gustatory signals to the hindbrain for central nervous system (CNS) processing.

\section{Transduction of sour taste}

\section{Acidic taste stimuli}

Sourness is mostly aversive unless combined with other tastes such as sweet. It is commonly accepted that sour taste is elicited by acids. Sour taste may function to protect against consuming excessive dietary acid and disturbing the body's vital acid-base balance. It has also been hypothesized that sour taste helps to avoid spoiled foods or unripened fruit. All these explanations are speculation, however. One of the earliest examples of the culinary use of sour tastants, apart from citrus fruits, is vinegar (or vin aigre, sour wine). Folklore suggests that vinegar was first produced in Babylonia 5000 BCE as a result of wine fermentation. Vinegar is principally a solution of acetic acid $(\sim 700 \mathrm{mM}$ to $1 \mathrm{M}$ ) having a $\mathrm{pH}$ of 2.3 to 2.6 (white vinegar). For comparison, the human detection threshold for acetic acid is $\sim 0.1 \mathrm{mM}$ [7], a solution having $\mathrm{pH} \sim 3.9$. Detection threshold for a common mineral acid, $\mathrm{HCl}$, is $6-10 \mathrm{mM}[8], \sim \mathrm{pH} 2$.

Is sourness evoked by the protons in an acid solution? Defining what is the precise stimulus in sour taste bears upon how sour taste is transduced by receptor cells, which is discussed below. Shallenberger [9] coined the term "common acidophore" for the functional group of sourtasting compounds. He considered the common acidophore was the simple proton (or more precisely, the hydronium ion, $\mathrm{H}_{3} \mathrm{O}^{+}$, because a proton in aqueous solutions is bound to one or more water molecules). Nonetheless, he recognized that, in the case of organic acids, the undissociated or partially dissociated acid molecules also contribute to sour taste. Indeed, it has long been recognized that sourness is not correlated simply with the concentration of protons in the stimulus solution (i.e., the $\mathrm{pH}$ ) [10]. Enigmatically, the sour intensity of dilute solutions of different organic and inorganic acids is only loosely correlated with their $\mathrm{pH}$ : acetic acid at $\mathrm{pH} 3.9$ evokes sour taste in humans, but $\mathrm{HCl}$ at this $\mathrm{pH}$ is relatively free of taste. Recordings from the chorda tympani nerve in rats show that stimulating the tongue with a solution of acetic acid at pH $5.5\left(\left[\mathrm{H}^{+}\right] \sim 3 \mu \mathrm{M}\right)$ generates a response that is matched by an $\mathrm{HCl}$ solution having a $\mathrm{pH}=3$ (i.e., $\left[\mathrm{H}^{+}\right]=1 \mathrm{mM}$ ), a 300 -fold greater concentration of protons than the effective acetic acid stimulus [11].

A number of studies in human psychophysics as well as studies on animal gustatory nerves and taste cells have attempted to determine precisely which component(s) of acids, especially organic acids, is (are) the active stimulus. Johanningsmeier et al. [12] conducted a metastudy of published data on human psychophysical rankings of the sourness of dilute solutions of citric acid, along with an analysis of malic, lactic, and acetic acids. They concluded that the best fit for concentration-response relations was obtained when sour intensity was plotted as a function of the sum total concentration of all the protonated molecular species plus the concentration of $\left[\mathrm{H}^{+}\right]$. Plotting sour intensity versus $\mathrm{pH}$ alone (i.e., versus $\left[\mathrm{H}^{+}\right]$) produced a weaker correlation. In short, sourness was not a function of the concentration of protons in solution.

Figure 1 illustrates the calculations discussed in Johanningsmeier et al. [12] and Table 1 summarizes the sour stimuli commonly used in gustatory research.

Sour transduction mechanisms

Implicit in the above discussion is that the ligand for sourness is the proton and/or protonated species in the extracellular solution, i.e., in the taste stimulus. At first glance, this seems obvious. Yet, Lyall et al. [13] made the important observation that the proximate stimulus in sour taste appears to be the intracellular proton concentration, i.e., $\mathrm{pH}_{\mathrm{i}}$. Our laboratory has verified and extended this observation. Further, we showed that although applying an organic acid (citric) to taste buds decreased $\mathrm{pH}_{\mathrm{i}}$ broadly in all taste bud cells (and for that matter, the surrounding nonsensory epithelial cells), only a small subset of taste bud cells specifically responded to this $\Delta \mathrm{pH}_{\mathrm{i}}$ with a sour transduction signal, a $\mathrm{Ca}^{2+}$ transient [14]. In the same work, we also showed [14] that the $\mathrm{Ca}^{2+}$ transient elicited by $\Delta \mathrm{pH}_{\mathrm{i}}$ in the subset of sour-sensitive cells was generated by $\mathrm{Ca}^{2+}$ influx through voltage-gated calcium channels consequent to membrane depolarization. More recent findings, discussed later, indicate that these cells represent a specific type of taste cell (type III, presynaptic cell).

These observations fit well with the analysis of the effective stimulus for sour taste, discussed above. The protonated

Acid (sour) taste stimuli in solution. Organic acids dissociate into their component protonated molecular species in aqueous solutions. For instance, a $2 \mathrm{mM}$ solution of citric acid, $\mathrm{pH} 3$, elicits sourness and consists of the following distribution of molecular and ionic species:

$\begin{array}{cccc}\mathrm{H}_{3} \text { Citrate } & \mathrm{H}_{2} \text { Citrate }^{-}+\text {HCitrate }^{2-}+\text { Citrate }^{3-}+\mathrm{H}^{+} \\ 57 \% & 42 \% & 0.7 \% & 0.0003 \% \\ 1.14 \mathrm{mM} & 0.84 \mathrm{mM} & 14.7 \mu \mathrm{M} & 5.9 \mathrm{nM} 1 \mathrm{mM}\end{array}$

In the above example, the sum of the protonated species plus $\left[\mathrm{H}^{+}\right]$equals 2.99 $\mathrm{mM}$. For a monoprotic acid such as acetic acid at the same $\mathrm{H}^{+}$concentration (i.e., $\mathrm{pH} 3$, equivalent to $\sim 60 \mathrm{mM}$ acetic acid), the molecular species would be:

$\begin{array}{cl}\text { HAcetate } & \leftrightarrow \text { Acetate }^{-}+\mathrm{H}^{+} \\ 59 \mathrm{mM} & 1 \mathrm{mM}\end{array}$

and the effective stimulus concentration according to Johanningsmeier et al [12] would be $59 \mathrm{mM}+1 \mathrm{mM}=60 \mathrm{mM}$. Interestingly, for a given $\mathrm{pH}$, acetic acid is a more intense sour stimulus than citric acid, in accord with the above calculations for $\mathrm{pH} 3$ solutions of the two acids, and supporting the notion of Johanningsmeier et al [12].

In contrast to organic acids, common mineral acids, such as $\mathrm{HCl}$ and $\mathrm{H}_{2} \mathrm{SO}_{4}$, dissociate completely in aqueous solution. Their sourness is elicited by the concentration of protons, and thus, of $\mathrm{pH}$.

Fig. 1 Calculations discussed in Johanningsmeier et al. [12] 
Table 1 Common sour gustatory stimuli
Compound

Hydrochloric acid

Acetic acid<smiles>CC(=O)O</smiles>

Adipic acid<smiles>O=C(O)CCCCC(=O)O</smiles>

Citric acid<smiles>O=C(O)CC(O)(CC(=O)O)C(=O)O</smiles>

Fumaric acid<smiles>O=C(O)/C=C/C(=O)O</smiles>

Lactic acid

Malic acid<smiles>CC(O)C(=O)O</smiles>

Tartaric acid

\section{Structure}

$\mathrm{H}^{+} \mathrm{Cl}$

$$
\text { HO }
$$

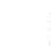

\section{Found in plants and animals as part of a} key metabolic pathway, the citric acid cycle. Citric acid is especially high in citrus fruits, kiwis and strawberries.

Found in fruits and vegetables and is part of the metabolic pathway in all cells. Used as a substitute for tartaric acid in baking powder.

Lactic acid is produced by bacteria in fermented foods and is present in large amounts in the large intestine where it is produced by resident gastrointestinal-tract bacteria. Fermented foods contain abundant lactic acid.

Present in most fruits and many vegetables. Also an important acid in wine, second to tartaric acid.

Found in fruits and vegetables and is a minor contributor to the acids in wine 
molecular forms of organic acids, especially the neutral, fullyprotonated species such as HAcetate or $\mathrm{H}_{3}$ Citrate readily permeate the cell membrane, enter the cytosol, and dissociate to release proton(s) inside the taste cell (Fig. 2). If present in high enough concentration (i.e., low $\mathrm{pH}$ ), extracellular protons will also cross the cell membrane, presumably through ion channels and ion exchangers such as the sodium-hydrogen exchanger (found in taste cells [15]), and acidify the cytoplasm, thereby explaining the sour taste of relatively concentrated solutions of $\mathrm{HCl}$ and other mineral acids.

Parenthetically, other routes of entry for extracellular protons might also exist, such as amiloride-sensitive epithelial sodium channels $(\mathrm{ENaC})$, which were shown to exhibit proton permeation in hamster taste cells [16]. Supporting this conclusion are behavioral studies on hamsters showing that amiloride reduces the aversive taste of acetic acid solutions [17]. However, blocking ENaC channels in mouse taste buds did not affect acid-stimulated taste responses [14], suggesting that it might not be possible to generalize the findings from the hamster model to mammalian sour-taste mechanisms as a whole. The role of $\mathrm{ENaC}$ in sour taste remains debatable.

In a sense, the notion that intracellular acidification is the proximate stimulus for sour taste does indeed implicate the proton as the "acidophore", borrowing Shallenberger's

Fig. 2 Schematic drawing showing a taste cell stimulated with acetic acid. Acetic acid in solution dissociates into a mixture of protonated acetic acid (HAcetate), acetate ${ }^{-}$, and protons $\left(\mathrm{H}^{+}\right)$, the latter of which are bound to one or more water molecules $\left(\mathrm{H}_{3} \mathrm{O}^{+}\right)$. HAcetate, being uncharged, penetrates the lipid plasma membrane and enters the cytosol. Inside the cell, HAcetate dissociates and releases $\mathrm{H}^{+}$ (which binds to $\mathrm{H}_{2} \mathrm{O}, \mathrm{H}_{3} \mathrm{O}^{+}$) and acetate $^{-}$, acidifying the cytosol (lowering $\mathrm{pH}_{\mathrm{i}}$ )

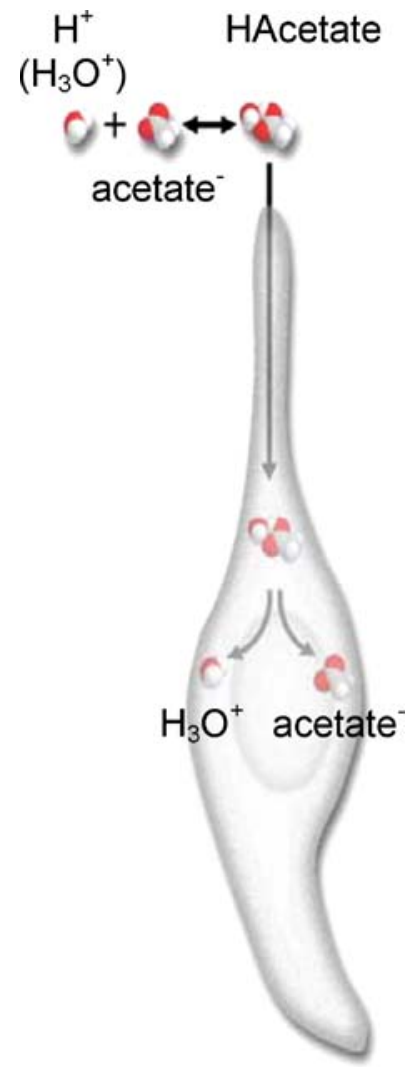

terminology. However, it is the intracellular, not the extracellular proton that is the active species, and this has implications for interpreting proposed acid-transduction mechanisms. The intracellular proton likely interacts with and binds to a cytoplasmic domain of membrane proteins.

Regrettably, however, the search to date for sour-taste transducers has focused attention mainly on mechanisms involving extracellular gating of one or another postulated acid-sensing channels or receptors. For instance, the family of acid-sensing ion channels (ASICs) is well established as comprising cation channels that are activated by extracellular protons in many tissues. Ugawa et al. [18] championed ASIC2a (formerly, MDEG1) as a candidate for sour taste based on his studies on rat taste cells and the sensitivity to acid solutions (varying extracellular $\mathrm{pH}$ ) of ASIC2a expressed in oocytes. Lin and Kinnamon [19] reported that acid-stimulated ion currents in rat taste cells had many properties that could be ascribed to ASIC channels. However, Richter et al. [20] showed that ASIC2a channels are not even expressed in mouse taste buds, despite this species' well-established ability to sense sour taste stimuli. Thus, ASIC2a channels are unlikely to represent a fundamental sour-taste mechanism in mammals.

Stevens et al. [21] proposed HCN1 and HCN4 channels for sour-taste transducers based on the expression of these channels in rat taste buds and the finding that extracellular acid stimulation modulated the hyperpolarization gated ion currents in rat taste cells. However, Richter et al. [14] found that blocking cyclic nucleotide-gated ion $(\mathrm{HCN})$ channels with $\mathrm{Cs}^{+}$had no effect on acid-evoked responses in mouse taste cells, challenging the generality of $\mathrm{HCN}$ channels as a basic mechanism in mammalian sour taste.

$\mathrm{ENaC}$ channels as mediators of sour taste have been mentioned above, but the absence of amiloride-sensitive acid taste responses is a serious challenge to this candidate for a sour-taste transducer. A possible caveat is that the channel inhibition by amiloride and other $\mathrm{ENaC}$ blockers might, itself, be acid-sensitive, such that the pharmacological agents are not active in low-pH solutions [22].

Another quite different possibility was recently put forward by Huque et al. [23], who speculated that GPR4, a proton-sensitive GPCR [24] that they found to be expressed in human fungiform papillae, was a sour receptor. These findings are intriguing, but a full report of the results remains to be published.

A recent addition to the gallery of candidate sour transducers is the transient receptor potential (TRP) family channel, PKD2L1, and its associated partner, PKD1L3. Lopez Jimenez et al. [25] first reported the expression of these channels in a subset of mouse taste cells. Later, Ishimaru et al. [26] confirmed and extended those findings by expressing PKD1L3 and PKD2L1 in HEK293 cells and showing that the transfected cells generated an inward current upon acid 
stimulation. Finally, Huang et al. [27] engineered mutant mice lacking the taste cells that express PKD2L1 and showed that these animals did not respond to sour-taste stimuli. A caveat for that finding is that the absence of an entire subpopulation of taste cells does not necessarily speak to the role of any given protein expressed by the missing cells. Nonetheless, collectively, the findings strongly implicate PKD2L1 and PKD1L3 as members of an acidtransducing matrix of channels (see next). Details about whether and to what extent PKD2L1 and PKD1L3 are modulated by intracellular $\mathrm{pH}$ remain to be established.

Lastly, Richter et al. [28] studied acid responses in mouse taste cells and concluded that a possible explanation for acid-taste transduction was the intracellular acidification of a matrix of membrane proteins, including certain $\mathrm{K}_{2} \mathrm{P}$ channels that are expressed in taste cells. This appears to be logical, given the likely potent effects of $\mathrm{pH}_{\mathrm{i}}$ on a variety of channels and receptors. For instance, TASK-1, a $\mathrm{K}_{2} \mathrm{P}$ channel found in taste cells, is blocked by intracellular (and extracellular) acidification [29]. Blocking TASK-1 would be expected to depolarize the membrane, open voltage-gated calcium channels, and admit $\mathrm{Ca}^{2+}$ to stimulate transmitter release.

In sum, taste bud cells involved in sour transduction have been identified, and some of the molecular details are emerging. Much remains to be discovered about the actual transduction machinery for acid stimuli, however. Attention has been focused on a search for a transducer protein(s) activated by extracellular protons, whereas the actual target appears more likely to be an intracellular site.

\section{Transduction of salty taste}

$\mathrm{NaCl}$, the prototypic salt stimulus

The principal stimulus for salty is a common ion, $\mathrm{Na}^{+}$. Table salt, $\mathrm{NaCl}$, is the prototypic salty tastant. $\mathrm{Na}^{+}$and $\mathrm{Cl}^{-}$ are essential nutrients, vital for maintaining blood volume, blood pressure, regulating body water, and in the case of $\mathrm{Cl}^{-}$, maintaining acid/base homeostasis (i.e., $\mathrm{Cl}^{-}$shift). The detection threshold for $\mathrm{NaCl}$ is 1 to $7 \mathrm{mM}$ in rodents and humans alike [30-32]. The human recognition threshold for $\mathrm{NaCl}$ is complicated by the variety of tastes that dilute $\mathrm{NaCl}$ elicits, such as sweet [33]. Other ions, including ammonium, lithium, and potassium, also stimulate salty taste but have pronounced other tastes in addition. It is claimed that the dipeptides ornithyltaurine and ornithyl- $\beta$ alanine evoke salty tastes and are effective salt substitutes $[34,35]$, but these findings have been disputed [36]. The issue is important because the chemical nature of the stimulus gives important information about the receptor mechanisms, which for salty, remain somewhat illusive.
Salty chemosensory transduction

An early attempt to explain salty taste attributed transduction to a protein or nucleic acid in the plasma membrane of taste cells that bound $\mathrm{Na}^{+}$[37]. A seminal finding was published by Heck et al. [38] in 1984 when they reported that $\mathrm{Na}^{+}$permeates cation channels in taste cells, specifically, amiloride-sensitive $\mathrm{ENaCs}$ (similar to those found in the kidney) on the anterior tongue. Passive $\mathrm{Na}^{+}$influx through ion channels, driven by the presence of $\mathrm{Na}$ salts in the stimulus (that is, $\mathrm{a} \mathrm{Na}^{+}$concentration gradient favoring $\mathrm{Na}^{+}$influx), would depolarize and thereby excite taste receptor cells.

The search for $\mathrm{ENaC}$ subunits has shown that the $\alpha, \beta$, and $\gamma$ subunits of $\mathrm{ENaC}$ are indeed expressed in taste buds $[39,40]$. Parenthetically, $\mathrm{ENaC}_{\beta}$ and $\mathrm{ENaC}_{\gamma}$ are less prominent in taste buds of the posterior tongue, possibly explaining the absence of amiloride-block for $\mathrm{Na}$ responses in taste buds from that region of the tongue. The presence of amiloride in $\mathrm{NaCl}$ solutions reduces the ability of rats and mice to distinguish $\mathrm{KCl}$ from $\mathrm{NaCl}$, which they normally can readily do [41, 42], supporting a role for amiloride-sensitive channels, possibly $\mathrm{ENaC}$, in $\mathrm{Na}^{+}$taste. However, the effects of amiloride are less clear on the taste of $\mathrm{NaCl}$ in humans [43, 44], raising some doubt about the role of amiloride-sensitive $\mathrm{ENaC}$ channels as a universal explanation for salt taste. A powerful approach to study the involvement of these channels in salt taste would be to examine mutant mice lacking one or more of the $\mathrm{ENaC}$ subunits [45]. Unfortunately, these gene knockout mice die shortly after birth.

Alternatively, a vanilloid receptor, V1R-like, was postulated to transduce $\mathrm{Na}^{+}$taste [46]. Subsequent behavioral studies using mutant mice lacking V1R (also known as TRPV1) did not reveal a lack of salt taste, however [47], challenging the hypothesis that this channel is involved in salt taste.

The consensus seems to be that there are both amiloridesensitive and amiloride-insensitive pathways in salt taste in mammals. How these pathways map onto specific $\mathrm{ENaC}$ subunits, if at all, remains to be determined.

Anions of sodium salts contribute to salty taste, particularly regarding taste intensity. $\mathrm{NaCl}$ evokes a stronger saltiness than $\mathrm{Na}$ sulphate, for example. One explanation for this involves the ability of $\mathrm{Na}^{+}$to permeate deep into the taste bud by penetrating through the tight junction spaces at the apical tips of cells [48]. The apical tips of taste bud cells, as in all epithelial boundaries, are sealed by a junctional complex including the zonula occudens. This is a specialized intercellular web that reduces access of ions and molecules in the external environment to the interstitial spaces of the taste bud. However, the apical cell-cell junctions are partially permeable to $\mathrm{Na}^{+}$and $\mathrm{Cl}^{-}$, represent- 
ing a paracellular leakage for $\mathrm{NaCl}$ and allowing access to the interior of the taste bud. Large anions such as $\mathrm{SO}_{4}^{2-}$, however, do not pass through the tight paracellular spaces and act as a brake, holding $\mathrm{Na}^{+}$back. Movement of $\mathrm{Na}^{+}$ unaccompanied by anions creates a charge separation and retards further movement of cations. When $\mathrm{Cl}^{-}$moves with $\mathrm{Na}^{+}$, there is no charge separation, and substantially more of the salt traverses the paracellular route. Penetration of $\mathrm{NaCl}$ into the interstitial spaces in the taste bud through apical paracellular pathways and the consequent increased intensity of salty-taste sensations suggest that chemosensory transduction mechanisms for $\mathrm{Na}^{+}$may be present along the basolateral membranes of taste cells as well as on the apical tips of taste bud cells.

\section{Transduction of sweet, bitter and umami tastes}

\section{Compounds that elicit sweet taste}

The prototypic sweet stimulus is sucrose, a disaccharide. Humans can detect sucrose at a concentration of 6-7 mM [49] and recognize it as a sweet taste around $25 \mathrm{mM}$ [50], although these values vary somewhat from study to study. A wide diversity of compounds elicit sweet taste (e.g., see [9]), including sugars, of course, such as monosaccharides (e.g., glucose, fructose, mannose), disaccharisdes (e.g., sucrose, lactose, maltose, trehalose), trisaccharides (e.g., raffinose), tetrasaccharides (stachyose), and, to some extent, even higher-level oligosaccharides (e.g., polycose, a partially hydrolyzed starch product). Some amino acids also elicit sweet taste, including glycine (from the greek, glykýs "sweet"), alanine, threonine, D-tryptophan, D-histidine (L-tryptophan and L-histidine are bitter), and others. Certain peptides and proteins are intensely sweet, most famously the methyl ester of the dipeptide L-aspartyl-L-phenylalanine ("aspartame") and the proteins brazzein [51] [54 amino acids (a.a.), molecular weight (MW) 6,473], monellin (94 a. a., MW 11,000) [52], and thaumatin (207 a.a., MW 22,000) [53]. Some alcohols, such as the aliphatic alcohols glycerol, sorbitol, and xylitol are sweet, too. In addition to these naturally-occurring sugars, alcohols, peptides, and proteins, there are a number of sweet synthetic compounds (ethylene glycol) and artificial sweeteners such as sucralose ("Splenda", a derivative of sucrose with $\mathrm{Cl}^{-}$substituted for three $\mathrm{OH}^{-}$groups), saccharine, and a host of others. Even simple ions elicit sweet taste, including dilute solutions of $\mathrm{NaCl}(10-30 \mathrm{mM}), \mathrm{LiCl}, \mathrm{KCl}$, and dangerously, the salts of beryllium and lead. One readily observes that the list of sweet compounds is vast and taxes the imagination to derive any common feature. Perhaps the most exhaustive attempt to find a common theme among sweet tastants is the work initiated by Shallenberger and Acree [54] (also see http://www.nysaes.cornell.edu/fst/faculty/acree/ahb/ acree 70.html). These researchers derived a "glycophore" consisting of an electronegative atom $\left(\mathrm{O}^{-}\right.$or $\left.\mathrm{N}^{-}\right)$designated as " $\mathrm{A}$ " that forms a hydrogen bond " $\mathrm{H}$ " with another nearby ( $\sim 0.3 \mathrm{~nm}$ distant) electronegative atom, "B", to form a leitmotif of AH-B found in all sweet compounds. This simple motif has been modified and expanded over the years in an effort to encompass all sweet compounds.

\section{T1Rs are GPC receptors for sweet taste}

The value of searching for a glycophore, among other things, was to help guide the isolation and purification of sweet-taste receptors. However, another approach, one utilizing molecular genetics, was eventually successful in identifying GPCRs that transduce sweet. Namely, in 1999, Hoon et al. [55] used differential screening of cDNA libraries constructed from single taste cells and from nontaste lingual tissue to identify two taste-specific GPCRs, TR1 and TR2 (later renamed T1R1 and T1R2). Hoon et al. speculated that, based on its pattern of expression on the tongue of these proteins, T1R1 (TR1) was a sweet receptor. Two years later, the human genome database that had just become available made it possible to search for genes related to T1R1 and T1R2. Several independent groups from USA and Japan scrutinized the human genome in a region comparable to a locus on chromosome 4 in mice, sac, that confers a taste preference for saccharin. This scan resulted in the identification of T1R3, a novel gene that was shown to be taste-specific and related to sweet-taste preference [56-61].

T1R1, T1R2, and T1R3 are all members of the large class C GPCRs that are typified by an extensive extracellular $\mathrm{N}$ terminus. Max et al. [58] predicted that T1R3 forms a dimer in the plasma membrane, based on comparisons with other closely related class C GPCRs, and specifically with metabotropic glutamate receptor 1 (mGluR1). A few months later, T1R3 was indeed shown to form a dimeric functional receptor, principally with T1R2 [60, 62]. The dimer, T1R2+T1R3, when expressed in HEK293 cells, conferred responsivity to sugars, and thus, T1R2+T1R3 was firmly established as the first identified sweet-taste receptor (Table 2). Homodimers of T1R3 (T1R3/T1R3) may also function as a sweet receptor [63], as predicted earlier.

In summary, the GPC dimeric taste receptor T1R2+T1R3 clearly is a central component of sweet taste, especially for artificial sweeteners. However, recent findings suggest there may be additional, yet undiscovered taste receptor(s) for sucrose and other sugars.

Where do ligands bind to T1R2 and T1R3?

Given the importance of the heterodimeric receptor T1R2+ T1R3 for sweet taste, recent studies have focused on how 
Table 2 Experiments designed to test the notion that T1R2+T1R3 dimer is a sweet receptor

\begin{tabular}{|c|c|}
\hline Strategy & Findings \\
\hline $\begin{array}{l}\text { Heterologous } \\
\text { expression }\end{array}$ & $\begin{array}{l}\text { When mouse or human T1R2+T1R3 receptors are expressed in HEK } 293 \text { cells, they confer a sensitivity, } \\
\text { absent in wild type cells, to a wide variety of sweet compounds, including sucrose, fructose, dulcin, } \\
\text { saccharin, and others; and for human T1R2+T1R3, cyclamate, aspartate, monellin, and thaumatin }[60,62] \text {. }\end{array}$ \\
\hline Molecular structure & Detailed investigations of T1R2 and T1R3 reveal specific sites for binding different sweet-tasting ligands $[64,66,67,69]$ \\
\hline Genetic modification & $\begin{array}{l}\text { Introducing T1R3 from a strain of mice in which sweet taste was normal ("taster" strain) into mice } \\
\text { lacking a strong preference to sugars ("non-taster" strain) rescued and restored behavioral responses } \\
\text { to saccharin and sucrose in the latter [60]. } \\
\text { Mice genetically modified to express human T1R2 yield animals with sweet preferences found only } \\
\text { in humans and not normally in mice [63]. }\end{array}$ \\
\hline Gene knock-out & $\begin{array}{l}\text { Responses to sweet tastes are suppressed in mutant mice lacking T1R2 and T1R3 (T1R knockout mice). } \\
\text { The findings and interpretations from different laboratories concerning these experiments and the primacy } \\
\text { of T1R2+T1R3 in sweet taste are somewhat conflicting, however. The laboratories of N. Ryba and C. Zuker } \\
\text { concluded that T1R2+T1R3 (and possibly the homodimer T1R3+T1R3) is the only receptor for sweet [63]. } \\
\text { However, Damak et al. [98], using a different knockout strategy, reported and emphasized that T1R3 } \\
\text { knockout mice had only diminished but otherwise measurable behavioral and nerve responses to sucrose, } \\
\text { glucose, and other sugars. Recently, Delay et al. [90] reported that the detection threshold for sucrose } \\
\text { was indistinguishable between T1R3 knockout and wild-type mice. Nonetheless, Damak et al. [98] } \\
\text { and Zhao et al. [63] both report that responses to artificial sweeteners were absent in the T1R3 knockout mice. }\end{array}$ \\
\hline
\end{tabular}

sweet compounds activate this dimer. An important concept that has emerged is that there are multiple binding pockets with different selectivities for different ligands. This may help explain the ability of the receptor to respond to such a wide range of sweet-tasting compounds as described above. The laboratories of X. Li, R. Margolskee, S. Munger, and P. Temussi are actively investigating the ligand-binding domains of T1R2 and T1R3. Temussi [64] has taken the approach of using computer modeling of the sweet binding site of the T1R dimer. They have analyzed the large extracellular domain, which has been shown to form a hinged ligand-binding pocket. This pocket is the so-called Venus flytrap (VFT) motif, first identified in another class C GPCR, mGluR1. Morini et al. [65] determined that a small region in the VFT of T1R2 and T1R3 may bind sugars, sweet amino acids, and other sweet compounds, and produce a conformational change in the "trap". It is uncertain whether the $\mathrm{N}$ termini of T1R2 and T1R3 interact allosterically in this binding or whether the two $\mathrm{N}$ termini function independently. Nie et al. [66] has used a novel technique to explore ligand binding of expressed $\mathrm{N}$ terminal domains of mouse T1R2 and T1R3. They have measured subtle changes in the spectroscopic properties of the purified $\mathrm{N}$ termini when stimuli, including sweet-taste compounds, are added to the $\mathrm{N}$ termini. There are key binding sites for sugars in the large extracellular $\mathrm{N}$ termini of T1R2 and T1R3 alike.

Jiang et al. [67] took advantage of the observation that the protein brazzein elicits intense sweet taste in humans but not in mice to parse different regions of the T1R2+T1R3 dimer and locate a binding site for sweet proteins. They constructed chimeras of the mouse and human T1R1+T1R3 and located a cysteine-rich region in T1R3 near the base of the $\mathrm{N}$ terminus that appears to be a binding pocket for brazzein and other sweet-tasting proteins. Using chimeric constructs of human and rat T1R1+T1R3 [68], or human and mouse T1R2+T1R3 followed by site-directed mutagenesis [69], researchers have narrowed down the cyclamate-binding pocket to portions of transmembrane segments 3,5 , and 6 of T1R3 and extracellular loop 2, suggesting that this pocket is mainly burrowed into the membrane. This contrasts with the N-terminal, extracellular binding domains for sugars and sweet proteins. Moreover, the cyclamate-binding pocket also appears to be where certain antagonists such as lactisole interact with the sweet receptor $[68,69]$.

These multiple binding pockets for different sweettasting compounds are illustrated in Fig. 3.

Chemosensory transduction and the intracellular cascades initiated by the T1R2+T1R3 sweet receptor are discussed below, in combination with transduction for the other GPCR-mediated tastes, bitter and umami.

\section{Compounds that elicit bitter taste}

If the wide range of different sweet-tasting compounds is impressive, the diversity of bitter compounds is astounding. Meyerhof [2] has recently attempted to categorize bitter compounds and has provided the most useful characterization of the universe of these tastants. Among the more intensely bitter compounds are amides, such as denatonium benzoate, and alkaloids such as strychnine, caffeine, and quinine. However, certain amino acids, urea, fatty acids, 


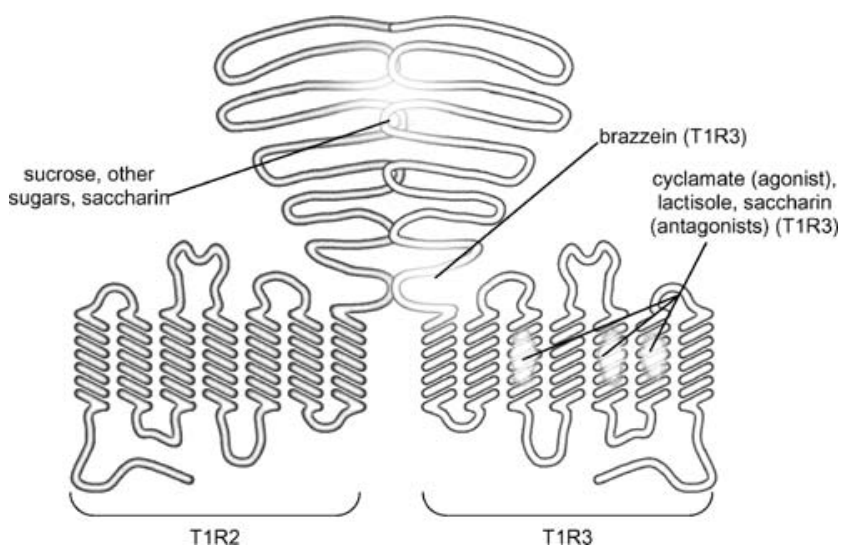

Fig. 3 Schematic drawing of the sweet GPCR dimer T1R2+T1R3, showing the multiple ligand binding sites. T1R2 is shown on the left, T1R3 is on the right. Details of the interactions, if any, between the extensive $\mathrm{N}$ termini of T1R2 and T1R3 are not known. The $\mathrm{N}$ termini possess one or more binding pocket(s) for saccharin, sucrose, and other sugars. Another ligand-binding pocket, located in T1R3 near the first transmembrane region, exists for certain sweet-tasting proteins such as brazzein. A third ligand pocket, embedded in the transmembrane (TM) regions of T1R3, is comprised of portions of TM3, 5, and 6. This site binds the artificial sweetener, cyclamate, but also is the binding site for antagonists such as saccharin (which at high concentrations is a sweet receptor antagonist) and lactisole

phenols, amines, esters, and other compounds also elicit bitterness. Even salts of potassium, magnesium, and calcium taste bitter. Many plants contain bitter compounds, including nutritionally important foods such as Cruciferous vegetables (e.g., arugula, broccoli, cauliflower, cabbage, watercress, and bok choy).

Because bitterness is generally an aversive taste and because many naturally-occurring toxic compounds taste bitter, it is commonly believed that bitter taste evolved to prevent animals from consuming harmful foodstuffs. Consistent with this interpretation, bitter taste on the whole has a lower threshold for activation, presumably to prevent consuming even small quantities of toxins. For example, the human detection threshold for caffeine is $133 \mu \mathrm{M}$ and for quinine is only $1.6 \mu \mathrm{M}$ [70]. Naive, neonatal humans and non-human primates reject bitter tastes [71]. However, with experience, humans learn to accept and even seek out bitter-tasting foods and drinks. Indeed, an intensely bitter vegetable of the Cucurbitaceae family, Momordica charantia (bitter melon), even has its own society to promote its consumption, the National Bitter Melon Council (http:// www.bittermelon.org/). Animals in the wild have been observed intentionally consuming bitter plants for purposes of self-medication [72]. In short, a wide diversity of compounds elicits bitterness, and conversely, bitterness elicits a variety of ingestive behaviors.

\section{T2Rs are GPC receptors for bitter taste}

GPCRs that transduce bitterness were first identified in 2000 by L. Buck's, N. Ryba's and C. Zuker's groups [73, 74]. These researchers exploited the newly published human genome database to search for candidate GPCRs in regions associated with bitter taste. For instance, Matsunami et al. [74] searched a region of human chromosome 12 corresponding to the sucrose octaacetate (SOA) locus on mouse chromosome 6, a portion known to control bitter taste. Adler et al. [73] chose to search for novel GPCR genes on human chromosome 5 in an area related to the ability of humans to taste propylthiouracil, a bitter compound. Both groups uncovered a large family of novel, taste-specific GPCRs for sensing bitter. Presently, 36 bitter-taste receptor genes and seven pseudogenes have been identified in the mouse [75] and 25 genes and 11 pseudogenes in the human [76]. These bitter receptors have been named T2Rs (also termed Tas2Rs).

Heterologous expression of the newly cloned mouse and human T2Rs in HEK293 cells confers the ability to respond to denatonium and cycloheximide, two intensely bitter compounds [77], verifying their role as bitter receptors. The role of T2Rs in bitter taste was confirmed and extended by more recent studies in native tissues: mice, genetically engineered to express candidate human bitter receptors such as hTAS2R38 for taste stimuli to which rodents normally do not respond (in the case of hTAS2R38, phenylthiocarbamide, see Table 3), manifest a taste aversion to those compounds [78]. In addition, mice expressing a K-opioid receptor under the control of a bitter receptor promoter

Table 3 Human bitter taste receptors and their agonists

\begin{tabular}{ll}
\hline Receptor [citation] & Ligand \\
\hline hTas2R16 [148] & $\begin{array}{l}\text { Salicin (a bitter-tasting beta-glucopyranoside found in the bark of willows and related to aspirin, } \\
\text { acetylsalicylic acid) } \\
\text { Phenylthiocarbamide (PTC), propylthiouracil (PROP) } \\
h T A S 2 R 38[149]\end{array}$ \\
$\begin{array}{l}\text { High concentrations of saccharin and acesulfame K (artificial sweeteners that evoke a bitter aftertaste in humans) } \\
\text { Absinthin, strychnine, and denatonium (the latter being one of the most intensely bitter compounds } \\
\text { for humans and used, for example, as a deterrent for nail biting and thumb sucking) }\end{array}$ \\
\hline
\end{tabular}


show a taste aversion to spiradoline, an opioid agonist that is normally tasteless to mice [78]. These studies validate the role of T2Rs (Tas2Rs) in bitter taste.

A focused search for ligands that activate the 25 human T2Rs (or hTas2Rs as the human bitter receptors are termed) is presently underway with at least five bitter-taste receptors and their ligands identified to date (Table 3).

Initially, it was reported that each bitter-responsive taste receptor cell expresses nearly the entire family of 2-3 dozen T2Rs [73]. This conclusion was based upon in situ hybridization (ISH) analyses in mouse taste buds. Namely, ISH with a mixture of probes for several mT2Rs did not label a significantly greater population of taste cells than ISH carried out with a probe for only one mT2R. This and related findings led Adler et al. [73] to conclude that there is a labeled line for bitter taste: any and all bitter compounds would stimulate a homogeneous population of T2R-expressing taste cells having a functional label, "bitter". These data conflicted with $\mathrm{Ca}^{2+}$ imaging studies showing that individual bitter-sensing cells responded to only one or a few bitter compounds and not broadly to all bitter tastants [79]. The issue appears to have been resolved recently by the careful ISH studies of Behrens et al. [80] using probes for hTAS2Rs. Bitter-sensing taste receptor cells do indeed express only subsets of TAS2Rs, not the entire family of receptors, at least in humans.

\section{Where do ligands bind to T2Rs?}

The structure of the bitter-taste GPCRs is strikingly different from that of the sweet-taste receptors. Namely, there is no evidence yet that the T2Rs (Tas2Rs) form dimers. Moreover, the extracellular $\mathrm{N}$ terminus of the bitter receptors is short and may not play a prominent role in ligand recognition. In this regard, the bitter-taste receptors are more similar to the class A (rhodopsin-like) GPCRs, although strictly speaking, they are not formally considered members of that category. Bitter-taste receptors form a class of their own.

Ongoing efforts are aimed at determining the agonist interaction sites for bitter receptors, similar to efforts discussed above for the sweet receptor. The extracellular loops and transmembrane domains that vary considerably from receptor to receptor within the family of bitter receptors are likely regions for these binding sites [81].

Compounds that elicit the taste, umami

The prototypic taste compound eliciting the savory or meaty taste termed "umami" (roughly translated from Japanese as "good taste") is the sodium salt of glutamate, or monosodium glutamate (MSG). This compound was extracted from dried kelp, a flavor additive in Oriental cuisines, and shown to be responsible for umami taste in
1908 by Kikunae Ikeda (English translation, [82]). Other compounds also elicit umami taste, namely, certain inosine and guanosine derivatives (inosine $5^{\prime}$-monophosphate, IMP; guanosine, 5'-monophosphate GMP). When presented in combination with MSG, IMP or GMP accentuate the umami taste in an unexplained synergistic mechanism. Glutamate and the nucleotide monophosphates occur naturally in many foods, especially meats, cheeses, tomatoes, even mother's milk, imparting umami taste. Additional compounds that also elicit umami taste include a select few amino acids other than glutamate (e.g., aspartate), certain di-, tri-, and higher-order peptides [83-85], synthetic glutamate-like compounds (L-AP4), and some organic acids [86].

$\mathrm{G}$ protein-coupled receptors for umami

A number of receptors for umami taste have been proposed over the past decade, beginning with the surmise of Faurion [87] that the umami-taste receptor might resemble brain synaptic receptors where glutamate is a neurotransmitter. A major difference between synaptic glutamate receptors and glutamate-taste (umami) receptors is the operating range for the ligand concentration. For central synapses, EC50 for glutamate is $\leq 100 \mu \mathrm{M}[88,89]$. In marked contrast, the threshold for MSG-taste detection in mice, rats, and humans is over tenfold higher, 1 to $2.5 \mathrm{mM}$ [90-92].

A candidate GPCR for umami taste was first identified by reverse transcriptase polymerase chain reaction (PCR) using primers for synaptic glutamate receptors, as Faurion had conjectured. Chaudhari et al. [93, 94] identified a truncated $\mathrm{N}$-terminal version of mGluR4 in rat taste buds and showed that Chinese hamster ovary $(\mathrm{CHO})$ cells expressing this receptor responded to L-glutamate in a concentration range appropriate for umami taste. Yang et al. [95] showed by ISH that mGluR4 was expressed in a subset of rat taste bud cells. Tests using genetic mutant mice lacking mGluR4 ("knockout mice") indeed showed significant behavioral alterations to the taste of MSG and not to $\mathrm{NaCl}$, sucrose, or saccharin [96]. Curiously, however, mGluR4 knockout mice preferred MSG to a greater extent than wild-type mice. However, these results were difficult to interpret because synaptic-mGluR4 and taste-mGluR4 alike were missing in the mutant strain. The absence of synaptic mGluR4 in the brain may well have influenced the perception of MSG and the taste behavioral assay.

Subsequently, in heterologous expression studies, investigators identified another candidate umami receptor, a dimer of T1R receptors, T1R1+T1R3 [62, 97]. HEK293 cells expressing this combination of T1Rs responded to glutamate and a number of other amino acids. Furthermore, adding low concentrations of IMP appeared to boost the responses to glutamate and other amino acids, 
mimicking the synergy reported for glutamate and nucleotide monophosphates in behavioral and nerverecording studies. An important test for the role of T1R1+T1R3 in umami taste was conducted by Zhao et al. [63]. They reported that mutant mice lacking either of these receptors showed a total absence of nerve responses or behavioral responses to MSG and other amino acids. However, other laboratories that have tried to replicate those studies reported somewhat different findings. Namely, Damak et al. [98] recorded reduced but still appreciable nerve and behavioral responses to glutamate in T1R3-null mice. Maruyama et al. [99] extended these studies by recording responses from individual taste cells in lingual slice preparations from mutant and wild-type mice. They also showed that although umami responses were somewhat diminished in T1R3-null mice, nonetheless, many cells responded to umami-taste stimulation. Collectively, the findings indicate that the taste of umami is likely to be transduced by T1R1+T1R3 dimers as well as other receptors, possibly taste-mGluR4, or by the newly reported truncated mGluR1 [100], or by as yet undiscovered receptors. It is possible that mGluR-taste receptors might themselves oligomerize, conceivably even with T1Rs, but this has not been tested as of yet.

Table 4 summarizes the discovery of taste GPCRs.

\section{Second-messenger cascades and taste GPCRs}

Cyclic adenosine monophosphate as a second messenger in taste

Two major streams of intracellular molecular interactions appear to be triggered by taste stimulation of taste GPCRs (i.e., sweet, bitter, and umami). The earliest identified tastetransduction stream involved the second messenger cyclic adenosine monophosphate (cAMP). Decades ago, Striem et al. [101] reported that treating membranes derived from the anterior surface of rat tongues with sucrose stimulated adenylyl cyclase, implying the presence of $\mathrm{G}_{\alpha \text { s }}$ proteins and

Table 4 Brief history of the discovery of candidate taste GPCRs

\begin{tabular}{|c|c|c|c|c|c|}
\hline Year & Taste receptor & & Citations & $\begin{array}{l}\text { Taste } \\
\text { stimulus }\end{array}$ & Strategy \\
\hline 1999 & $\begin{array}{l}\text { TR1, TR2 renamed } \\
\text { T1R1, T1R2 } \\
\text { (Adler et al. [73]) }\end{array}$ & $\begin{array}{l}\text { Members of the large family } \\
\text { of class C GPCRs, typified by } \\
\text { lengthy N termini having a } \\
\text { Venus flytrap motif }\end{array}$ & Hoon et al. [55] & Unknown in 1999 & $\begin{array}{l}\text { Large-scale sequencing } \\
\text { of a subtracted cDNA library } \\
\text { (nontaste-taste } \\
\text { cell cDNA) derived from } \\
\text { lingual tissue }\end{array}$ \\
\hline 2000 & Taste-mGluR4 & $\begin{array}{l}\mathrm{N} \text { terminal truncated version } \\
\text { of the metabotropic glutamate } \\
\text { receptor, mGluR4, also a } \\
\text { class C GPCR }\end{array}$ & $\begin{array}{l}\text { Chaudhari } \\
\text { et al. [92] }\end{array}$ & $\begin{array}{l}\text { Umami (monosodium } \\
\text { glutamate) }\end{array}$ & $\begin{array}{l}\text { Focussed search with primers } \\
\text { based on synaptic glutamate } \\
\text { receptors }\end{array}$ \\
\hline 2000 & $\begin{array}{l}\text { T2Rs (also known } \\
\text { as Tas2Rs, } \\
\text { Bufe et al. [148]) }\end{array}$ & $\begin{array}{l}\text { A large family of GPCRs } \\
(N \sim 40 \text { in mice) with short N } \\
\text { termini. The T2Rs are most } \\
\text { closely related to the class A } \\
\text { (rhodopsin-like) GPCRs but } \\
\text { are considered as a } \\
\text { separate category. }\end{array}$ & $\begin{array}{l}\text { Adler et al. [73]; } \\
\text { Chandrashekar } \\
\text { et al. [77]; } \\
\text { Matsunami et al. [74] }\end{array}$ & Bitter & $\begin{array}{l}\text { Data mining of newly available } \\
\text { human genome for GPCRs } \\
\text { in a region associated with } \\
\text { the ability to taste PROP } \\
\text { or SOA }\end{array}$ \\
\hline 2001 & $\begin{array}{l}\text { T1R3 (also known } \\
\text { as Tas1r3) }\end{array}$ & $\begin{array}{l}\text { A class C GPCR similar } \\
\text { to T1R1 and T1R3 }\end{array}$ & $\begin{array}{l}\text { Bachmanov et al. [56], } \\
\text { Kitagawa et al. [57], } \\
\text { Max et al. [58], } \\
\text { Montmayeur et al. [59], } \\
\text { Nelson et al. [60], } \\
\text { Sainz et al. [61] }\end{array}$ & Sweet & $\begin{array}{l}\text { Data mining of newly available } \\
\text { human genome for GPCRs in } \\
\text { the human equivalent of the } \\
\text { sac locus from mice }\end{array}$ \\
\hline $2001-2003$ & $\begin{array}{l}\text { T1R2/T1R3 } \\
\text { (and possibly } \\
\text { T1R3/T1R3) }\end{array}$ & $\begin{array}{l}\text { A heterodimer of } \\
\text { T1R2+T1R3 }\end{array}$ & $\begin{array}{l}\text { Nelson et al. [60], } \\
\text { Li et al. [62], } \\
\text { Zhao et al. [63] }\end{array}$ & Sweet & $\begin{array}{l}\text { Heterologous expression } \\
\text { in HEK } 293 \text { cells }\end{array}$ \\
\hline 2003 & T1R1/T1R3 dimer & $\begin{array}{l}\text { A heterodimer of } \\
\text { T1R1+T1R3 }\end{array}$ & Zhao et al. [63] & $\begin{array}{l}\text { Umami (monosodium } \\
\text { glutamate) }\end{array}$ & $\begin{array}{l}\text { Heterologous expression } \\
\text { in HEK293 cells }\end{array}$ \\
\hline 2005 & Taste-mGluR1 & $\begin{array}{l}\mathrm{N} \text { terminal truncated } \\
\text { version of mGluR1, } \\
\text { also a class C GPCR }\end{array}$ & San Gabriel [100] & $\begin{array}{l}\text { Umami (monosodium } \\
\text { glutamate) }\end{array}$ & $\begin{array}{l}\text { Focussed search with } \\
\text { primers based on synaptic } \\
\text { glutamate receptors }\end{array}$ \\
\hline
\end{tabular}


cAMP pathways in taste. These studies have been replicated and extended, using intact taste tissue [102]. Further, cAMP depolarizes frog and mouse taste cells, presumably due to cAMP-dependent protein kinase-phosphorylating and closing potassium channels [103, 104]. Fast quench flow measurement of second messengers after taste stimulation in rat taste buds revealed that sucrose induces an initial increase in cyclic GMP earlier and more transiently than changes in cAMP [105]. The significance of an early transient cyclic nucleotide signal is unclear. Krizhanovsky et al. [105] speculated that changes in intracellular cAMP occur later during taste stimulation and might be involved in more long-term effects, such as adaptation.

In 1992, McLaughlin et al. [106] identified a taste-specific $\mathrm{G}$ protein, $\mathrm{G}_{\alpha}$ gustducin, that resembles transducin. By analogy with transducin, taste receptor activation of $\mathrm{G}_{\alpha}$ gustducin was initially believed to be negatively coupled to cAMP. This differed with the positive coupling reported for sucrose taste. Indeed, direct measurements of cAMP after bitter taste verified that this second messenger declines with bitter stimulation [107]. Trubey et al. [102] also showed that umami-taste stimulation also causes a decrease in cAMP in rat taste buds, emphasizing the presence of transducin-like $\mathrm{G}$ proteins in taste cells. That $\mathrm{G}_{\alpha}$ gustducin is intimately involved in bitter, umami, and sweet stimulation has been verified by showing that these taste qualities are significantly compromised in $\mathrm{G}_{\alpha}$ gustducin knockout mice [108-111].

Events downstream of changes in intracellular cAMP and that lead to transmitter release from taste cells have not been investigated in much detail. The original findings of Avenet et al. [103] mentioned above suggest that protein kinase A-mediated phosphorylation and inhibition of a potassium conductance could lead to membrane depolarization, thereby stimulating voltage-gated $\mathrm{Ca}^{2+}$ channels and allowing $\mathrm{Ca}^{2+}$ influx as a prelude to transmitter secretion. A somewhat different role for $\mathrm{Ca}^{2+}$ in taste cells is discussed next.

Involvement of the second messenger cAMP in sour and salty tastes, taste qualities that are not believed to be transduced by GPCRs, is not as well understood if it occurs at all.

\section{Calcium as a second messenger in taste}

The second major intracellular messenger stream that has been defined and which has been the focus of substantial attention in recent years is inositol 1,4,5-trisphosphate (IP3)-mediated release of intracellular $\mathrm{Ca}^{2+}$. The proteins and other mediators involved in this second messenger cascade have been identified in taste cells, including the discovery of a taste-specific isoform of phospholipase $\mathrm{C}$ (PLC 32 ) [112], the presence of IP3R3 receptors in taste cells [113], the measurement of taste-evoked IP3 increases $[114,115]$, and the all-important observation that taste stimulation indeed evokes intracellular $\mathrm{Ca}^{2+}$ release [116, 117]. Notably, single-cell PCR experiments show that all the proteins in the PLC $\beta 2-I P 3-\mathrm{Ca}^{2+}$ pathway are expressed in the same cell, the taste receptor cell [118, 119]. Lastly, mutant mice lacking PLC $\beta 2$ show compromised responses to sweet, umami, and bitter tastes [120].

That the PLC $32-I P 3-\mathrm{Ca}^{2+}$ cascade is important in taste is undeniable, but it is not the exclusive pathway for taste. Dotson et al. [121] showed that PLC $\beta 2$ knockout mice have reduced responses to bitter-taste stimulation but not a complete absence of bitter taste. Clearly, pathways for chemosensory transduction that do not rely on PLC $\beta 2$ are present in taste cells.

Finally, another key participant in chemosensory transduction is the nonselective monovalent cation channel TRPM5. TRPM5 is expressed in a number of neuronal and epithelial cells, including taste bud cells and chemosensitive cells in the gut [122-126]. Taste cells and some gut cells that express TRPM5 also express taste receptors and other elements of the PLC $\beta 2$-signaling stream [118, 120, 125]. Significantly, genetic knockout of TRPM5 renders mice less responsive to sweet, bitter, and umami tastes [120, 127].

Initially, it was believed that in response to taste stimulation, PLC $\beta 2$ directly or indirectly gated TRPM5 [120] or that depletion of $\mathrm{Ca}^{2+}$ from internal stores activated TRPM5 [128]. However, more recent findings show that TRPM5 channels are transiently and directly opened by small and rapid increases of intracellular $\mathrm{Ca}^{2+}$, such as those generated during taste stimulation as a consequence of the PLC $\beta 2$ signaling stream $[123,124,126]$. The net result of TRPM5 activation would be cation influx and membrane depolarization, presumably leading to neurotransmitter release. Interestingly, ion currents through TRPM5 are enhanced by temperature elevation in a physiologically relevant range, 15 to $35^{\circ}$ [129]. This heat sensitivity of TRPM5 may explain the increase in sweet-taste intensity with temperature increases over this same range [129].

Figure 4 summarizes the two intracellular cascades of receptors and downstream effectors initiated by taste stimulation.

\section{Information flow in the taste bud}

A second intriguing aspect of peripheral mechanisms in taste is the finding that some degree of information processing occurs in taste buds. Researchers now recognize that there are functionally distinct populations of cells in mammalian taste buds, including separate populations of receptor cells and cells with synapses. Morphologically distinct taste cell types have been described from the earliest histological identification of taste cells up through 
Fig. 4 Taste stimulation for $\mathrm{G}$ protein-coupled taste receptors (e.g. sweet, bitter, umami) initiates two parallel streams of intracellular events. Several details are known for the PLC $\beta 2$-signaling stream (right). Considerably less is understood about the role of cyclic nucleotides in taste transduction (left), especially taste-evoked decreases in cAMP. The final events shown, depolarization leading to transmitter release, remain somewhat speculative

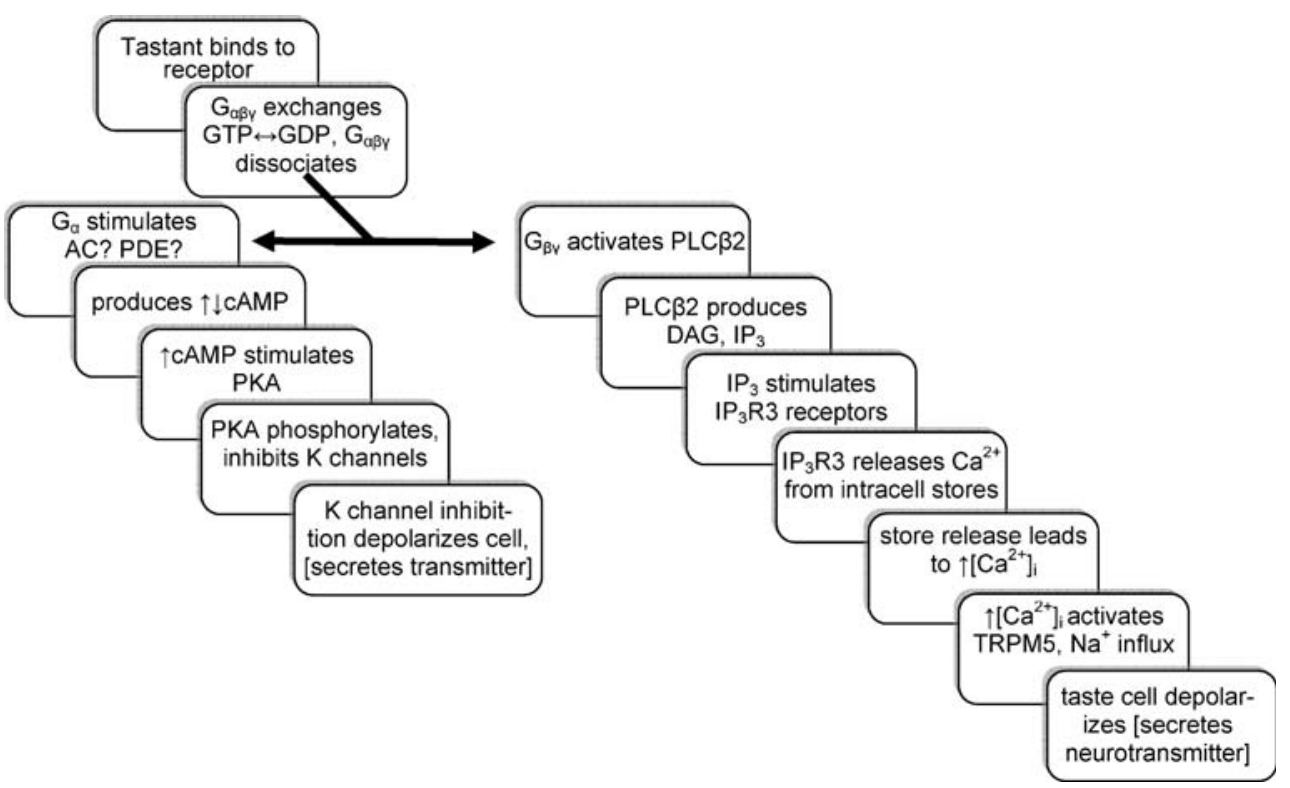

electron microscopical studies (light microscopy: light cells, dark cells; electron microscopy: types I, II, III, and IV cells; reviewed [130]). Yet until of late, there has been no clear assignment of function to cell morphotype. Recent studies employing immunostaining suggested that proteins involved in the initial events of chemosensory transduction, such as taste GPCRs, $\mathrm{G}_{\alpha}$ gustducin, PLC $\beta 2$, and TRPM5, are expressed in one type of cell (type II), but proteins involved in synapses and synaptic release of transmitters, such as SNAP-25 and neural cell adhesion molecule (NCAM), are present in a different type of taste cell (type III) $[118,119,131,132]$. Functional imaging of isolated taste bud cells followed by single-cell PCR definitively revealed the existence of two separate classes of taste cells [118]. One class of taste cell responds to taste stimulation, indicating these are sensory receptor cells (formerly known as type II cells). Sensory receptor cells express taste GPCRs, PLC $\beta 2$, IP3R3, and TRPM5-proteins underlying known transduction cascades, reviewed above. The second class of cells is excited by depolarization with $\mathrm{KCl}$ but $n o t$ by taste stimulation. These latter cells express a voltage-gated $\mathrm{Ca}^{2+}$ channel (namely, $\alpha 1 \mathrm{~A}$ ), NCAM, and SNAP-25, i.e., proteins associated with synapses. These cells have been termed presynaptic cells (formerly known as type III cells) [118]. Presynaptic (type III) cells are the only cells in the taste bud that possess ultrastructural features of synapses (vesicles and synaptic thickenings). This raises the conundrum that the cells that directly respond to gustatory stimulation, i.e., taste receptor (type II) cells, are not the cells that make synapses, i.e., presynaptic (type III) cells. A possible resolution to this is described next.
Finger et al. [133] showed that adenosine triphosphate (ATP) is one of the neurotransmitters that activate gustatory primary afferent fibers. They found that mutant mice lacking P2X2 and P2X3 receptors had greatly reduced gustatory nerve and taste behavioral responses to glutamate (umami taste), sweeteners, and bitter compounds. These P2X purinoceptors had previously been localized to sensory afferent terminals innervating taste buds. Further, Finger et al. [133] measured tastant-evoked ATP secretion from pieces of lingual epithelium containing taste buds. Subsequently, Huang et al. $[134,135]$ used focal biosensor cells to demonstrate that individual sensory receptor (type II) cells in the taste bud secrete ATP when stimulated and that presynaptic (type III) cells release serotonin (5-HT). Further, Huang et al. [135] revealed that ATP also acts as a cell-cell mediator between receptor and presynaptic cells. Thus, ATP secretion from receptor cells during taste stimulation excites sensory afferent fibers and adjacent presynaptic cells concurrently (Fig. 5). In brief, chemosensory excitation of taste buds triggers release of ATP and serotonin alike.

Although evidence for a neurotransmitter role for ATP is firm, serotonin's function in taste buds remains puzzling. In their report on purinergic neurotransmission in taste buds, Finger et al. [133] commented that mutant mice lacking one of the serotonin receptor subtypes, 5-HT3, showed no obvious taste-behavior abnormalities. Yet, there is substantial literature implicating serotonin as a taste bud neurotransmitter or neuromodulator [136]. The involvement of other receptor types on taste cells and nerves remains to be explored fully. For example, Kaya et al. [137] reported that 5-HT1A receptors are expressed on taste cells and proposed 


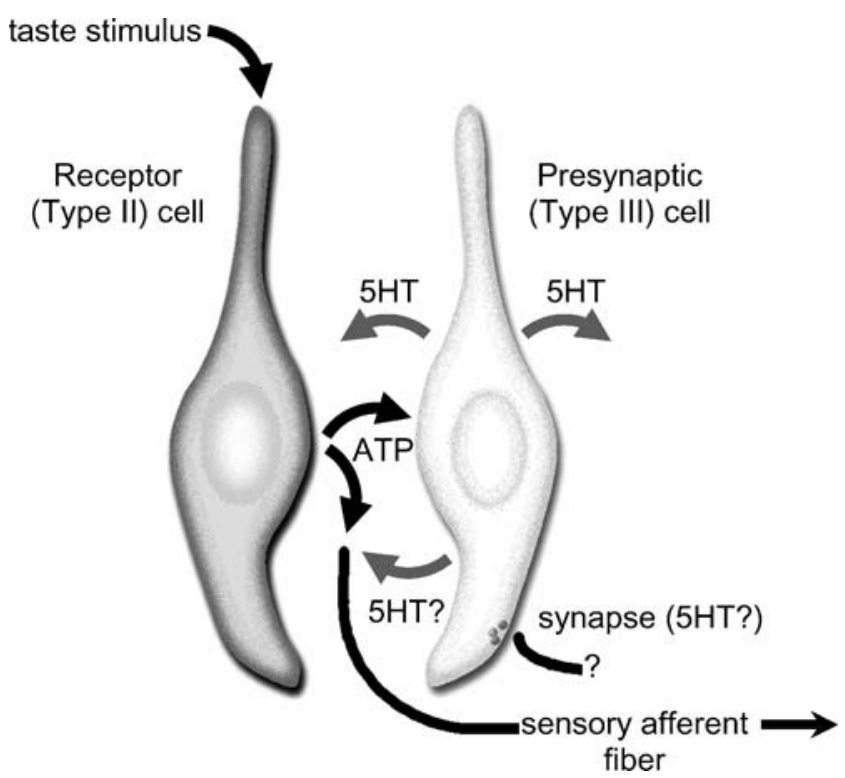

Fig. 5 Cell-cell communication within the mammalian taste bud. Taste receptor (type II) cells (left) secrete ATP in response to gustatory stimulation. ATP acts on sensory afferent fibers as well as on adjacent presynaptic (type III) cells (right), causing the latter to release serotonin (5HT). Consequently, gustatory stimulation of taste buds elicits ATP and serotonin release. Presynaptic cells form synapses, possibly serotonergic, with targets that have not yet been identified with confidence. Postsynaptic sites for 5HT may include other taste cells (paracrine activation), sensory afferent fibers, or unidentified postsynaptic targets, as shown above

that serotonin is a paracrine transmitter at 5-HT1A receptors in taste buds. Serotonin may modulate the threshold of sensory receptor cells in the taste bud or alter membrane properties in taste bud cells [138, 139]. Indeed, a recent report from L. Donaldson's laboratory shows selective serotonin re-uptake inhibitors alter human taste thresholds for sweet and bitter via a peripheral mechanism [140]. Further investigation of the role of serotonin in taste buds is clearly needed.

The finding that taste receptor cells secrete ATP onto sensory afferent fibers and onto nearby serotonergic taste cells may resolve the nagging problem that gustatory sensory receptor cells lack ultrastructural features associated with synapses, such as clusters of synaptic vesicles and presynaptic membrane thickenings. It seems that novel synaptic mechanisms, not involving exocytosis at welldefined synapses, underlie ATP secretion from sensory receptor cells. This arrangement might also explain why electrophysiological recordings from primary sensory axons often indicate that a single fiber can respond to two or more different taste qualities (e.g., sweet and bitter), and yet, taste receptor cells express only one type of GPCR, e.g., sweet or bitter, but not both. Namely, a single sensory afferent fiber could respond to ATP secreted from a small number of nearby taste receptor cells, which might not all express the same type of taste receptor. Further, ATP secreted from multiple taste receptor cells, including cells expressing different taste receptors, may be able to excite one presynaptic cell. That is, different types of receptor cells might converge onto one presynaptic cell. Thus, multipleresponsive taste cells that are reported from patch-clamp studies [141, 142] and $\mathrm{Ca}^{2+}$ imaging [79] would correspond to activity in presynaptic (type III) cells, not receptor (type II) cells

Such an arrangement would explain the presence of taste cells that are "tuned" to one taste quality, e.g., sweet (receptor cells expressing T1R2+T1R3) alongside taste cells that respond to multiple qualities, e.g., sweet and bitter (presynaptic cells excited by ATP secreted from sweet-sensitive and bitter-sensitive receptor cells), as is
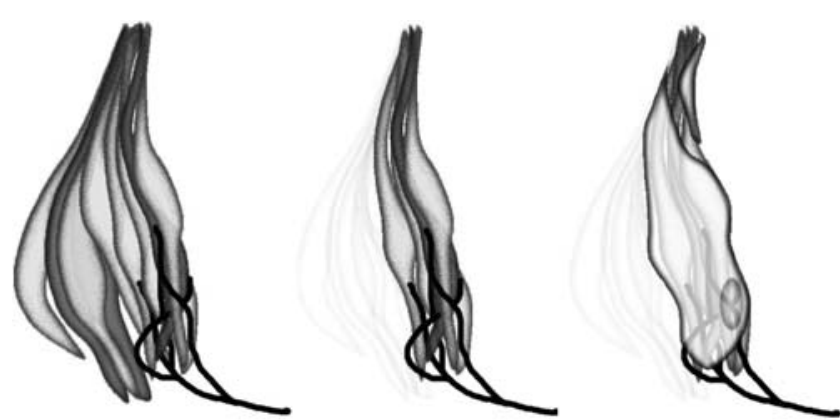

Fig. 6 Schematic drawing of a mammalian taste bud illustrating hypothetical clustering of receptor (type II) and presynaptic (type III) cells for information coding. Left, nine representative taste cells (out of a total of 50 to 100 , typical of taste buds) are depicted. A single sensory afferent axon is shown innervating a cluster of taste cells. For clarity, afferent innervation of other cells has been omitted. ATP secreted from receptor (type II) cells (light gray) excites afferent axons. ATP from receptor cells also stimulates presynaptic (type III) cells (dark gray). Middle, the cluster of cells contacting the afferent fiber is isolated for emphasis. Three receptor cells, each of which might express a similar taste GPCR, are shown for illustration. Activation of any of the receptor cells in the cluster would result in ATP secretion and excitation of the afferent fiber. ATP would also excite the presynaptic cell shown in the middle of the cluster. Right, a type I supporting cell ensheathing the cluster of taste cells is added. Type I cells express ecto-ATPase which would be expected to limit the diffusional spread of ATP throughout the taste bud, perhaps concentrating its actions on small clusters of cells as shown here. Even though each receptor cell expresses one type of taste GPCR, the information carried by the single sensory afferent (i.e., its "code") might be ambiguous if not all the receptor cells in the cluster expressed identical taste GPCRs. Further, activity in the presynaptic (type III) cell would reflect stimulation of any of the nearby receptor cells. However, gustatory coding from the entire taste bud or multiple taste buds could be resolved if activity in numbers of sensory afferents were combined or averaged. Such a schema might explain how electrophysiological and functional imaging studies report the existence of taste cells that respond to multiple taste stimuli (here, presynaptic (type III) cells) alongside cells that respond only to one tastant (i.e., receptor (type II) cells). The schema would also explain the multiple taste sensitivity recorded from single afferent fibers 
observed. Similarly, sensory afferent fibers would respond predominantly to ATP secreted from receptor cells that they most closely abutted but might also be somewhat affected by ATP released from other nearby receptor cells. This would explain the existence of "sweet-best", or "bitter-best" responsive taste afferents and not of exclusively sweet-, or exclusively bitter-responsive sensory afferents.

Type I taste bud cells (putative supporting cells) are likely to prevent ATP secreted from receptor cells from diffusing widely throughout the taste bud during taste stimulation. This would provide some degree of specificity for purinergic signaling between receptor cells and afferent axons. Type I cells ensheath surrounding cells with lamellar processes [143]. This wrapping alone might limit ATP diffusion within the taste bud. However, in addition, type I cells express a potent ecto-ATPase [144] that breaks down ATP. This ecto-ATPase would further limit ATP spread during taste stimulation. Conceivably, type I cells may even enwrap small clusters of receptor and presynaptic cells and their sensory afferent innervation, providing a protected environment for cell-cell communication among selected subgroups of taste cells (Fig. 6). Such an organization is speculation, however, and would require detailed 3 -D reconstructions of taste buds at the ultrastructural level.

The presence of sensory afferent fibers that respond to multiple taste qualities has led to the concept of "cross-fiber" or combinatorial coding for gustatory information leaving the taste bud (reviewed [145]). The temporal pattern of action potentials excited by taste stimuli has been put forward as providing additional information about the nature of the chemical stimulus. However, most of the experimental effort aimed at this notion has been carried out by recording from CNS neurons involved in taste [146, 147]. A full understanding of taste coding in the CNS will require a better understanding of how the initial signals are specified in the peripheral sensory organs, the taste buds. As this review has indicated, considerable progress is currently being made along those lines. We have recently identified a novel transmitter release mechanism for ATP not involving vesicular exocytosis [151]. Receptor (type II) cells secrete ATP via pannexin 1 hemichannels during taste stimulation. Another group confirmed connexin and pannexin expression in lingual tissue and speculated that either or both may be involved in ATP release from taste cells [152].

\section{References}

1. Simon SA, de Araujo I, Gutierrez R, Nicolelis MA (2006) The neural mechanisms of gustation: a distributed processing code. Nat Rev Neurosci 7:890-901

2. Meyerhof W (2005) Elucidation of mammalian bitter taste. Rev Physiol Biochem Pharmacol 154:37-72
3. Spector AC, Travers SP (2005) The representation of taste quality in the mammalian nervous system. Behav Cogn Neurosci Rev 4:143-191

4. Breslin PA, Huang L (2006) Human taste: peripheral anatomy, taste transduction, and coding. Adv Oto-Rhino-Laryngol 63:152-190

5. Gilbertson TA (1998) Gustatory mechanisms for the detection of fat. Curr Opin Neurobiol 8:447-452

6. Sclafani A, Ackroff K, Glendinning JI, Abumrad NA, Margolskee RF (2006) Fat flavor preferences in CD36, TRPM5 and gustducin knockout mice. Chem Senses 31:E56

7. Stevens JC (1997) Detection of very complex taste mixtures: generous integration across constituent compounds. Physiol Behav 62:1137-1143

8. Kamath S, Booth P, Lad TE, Kohrs MB, McGuire WP (1983) Taste thresholds of patients with cancer of the esophagus. Cancer 52:386-389

9. Shallenberger RS (1993) Taste chemistry. Blackie Academic and Professional, London

10. Harvey RB (1920) The relation between the total acidity, the concentration of the hydrogen ion, and the taste of acid solutions. J Am Chem Soc 42:712-714

11. Ogiso K, Shimizu Y, Watanabe K, Tonosaki K (2000) Possible involvement of undissociated acid molecules in the acid response of the chorda tympani nerve of the rat. J Neurophysiol 83:27762779

12. Johanningsmeier SD, McFeeters RF, Drake M (2005) A hypothesis for the chemical basis for perception of sour taste. J Food Sci 70:R44-R48

13. Lyall V, Alam RI, Phan DQ, Ereso GL, Phan TH, Malik SA, Montrose MH, Chu S, Heck GL, Feldman GM, DeSimone JA (2001) Decrease in rat taste receptor cell intracellular $\mathrm{pH}$ is the proximate stimulus in sour taste transduction. Am J Physiol Cell Physiol 281:C1005-C1013

14. Richter TA, Caicedo A, Roper SD (2003) Sour taste stimuli evoke $\mathrm{Ca}^{2+}$ and $\mathrm{pH}$ responses in mouse taste cells. J Physiol 547:475-483

15. Vinnikova AK, Alam RI, Malik SA, Ereso GL, Feldman GM, McCarty JM, Knepper MA, Heck GL, DeSimone JA, Lyall V (2004) $\mathrm{Na}^{+}-\mathrm{H}^{+}$exchange activity in taste receptor cells. J Neurophysiol 91:1297-1313

16. Gilbertson TA, Roper SD, Kinnamon SC (1993) Proton currents through amiloride-sensitive $\mathrm{Na}+$ channels in isolated hamster taste cells: enhancement by vasopressin and cAMP. Neuron 10:931-942

17. Gilbertson DM, Gilbertson TA (1994) Amiloride reduces the aversiveness of acids in preference tests. Physiol Behav 56:649-654

18. Ugawa S, Minami Y, Guo W, Saishin Y, Takatsuji K, Yamamoto T, Tohyama M, Shimada S (1998) Receptor that leaves a sour taste in the mouth. Nature 395:555-556

19. Lin W, Ogura T, Kinnamon SC (2002) Acid-activated cation currents in rat vallate taste receptor cells. J Neurophysiol 88:133141

20. Richter TA, Dvoryanchikov GA, Roper SD, Chaudhari N (2004) Acid-sensing ion channel-2 is not necessary for sour taste in mice. J Neurosci 24:4088-4091

21. Stevens DR, Seifert R, Bufe B, Muller F, Kremmer E, Gauss R, Meyerhof W, Kaupp UB, Lindemann B (2001) Hyperpolarizationactivated channels HCN1 and HCN4 mediate responses to sour stimuli. Nature 413:631-635

22. Ugawa S, Yamamoto T, Ueda T, Ishida Y, Inagaki A, Nishigaki M, Shimada S (2003) Amiloride-insensitive currents of the acidsensing ion channel-2a (ASIC2a)/ASIC2b heteromeric sour-taste receptor channel. J Neurosci 23:3616-3622

23. Huque T, Lischka FW, Bresliin PA, Feldman RS, Spielman AI, Brand JG (2006) Expression of GPR4, a proton sensing GPCR, in human fungiform papillae. Chem Senses in press 
24. Ludwig MG, Vanek M, Guerini D, Gasser JA, Jones CE, Junker U, Hofstetter H, Wolf RM, Seuwen K (2003) Proton-sensing G-protein-coupled receptors. Nature 425:93-98

25. Lopez Jimenez ND, Cavenagh MM, Sainz E, Cruz-Ithier MA, Battey JF, Sullivan SL (2006) Two members of the TRPP family of ion channels, Pkd113 and Pkd211, are co-expressed in a subset of taste receptor cells. J Neurochem 98:68-77

26. Ishimaru $\mathrm{Y}$, Inada $\mathrm{H}$, Kubota $\mathrm{M}$, Zhuang $\mathrm{H}$, Tominaga $\mathrm{M}$, Matsunami H (2006) Transient receptor potential family members PKD1L3 and PKD2L1 form a candidate sour taste receptor. Proc Natl Acad Sci U S A 103:12569-12574

27. Huang AL, Chen X, Hoon MA, Chandrashekar J, Guo W, Trankner D, Ryba NJ, Zuker CS (2006) The cells and logic for mammalian sour taste detection. Nature 442:934-938

28. Richter TA, Dvoryanchikov GA, Chaudhari N, Roper SD (2004) Acid-sensitive two-pore domain potassium $\left(\mathrm{K}_{2} \mathrm{P}\right)$ channels in mouse taste buds. J Neurophysiol 92:1928-1936

29. Kim Y, Bang H, Kim D (1999) TBAK-1 and TASK-1, two-pore $\mathrm{K}(+)$ channel subunits: kinetic properties and expression in rat heart. Am J Physiol 277:H1669-H1678

30. Eylam S, Spector AC (2002) The effect of amiloride on operantly conditioned performance in an $\mathrm{NaCl}$ taste detection task and $\mathrm{NaCl}$ preference in $\mathrm{C} 57 \mathrm{BL} / 6 \mathrm{~J}$ mice. Behav Neurosci 116:149-159

31. Clarke SN, Koh MT, Bernstein IL (2001) NaCl detection thresholds: comparison of Fischer 344 and Wistar rats. Chem Senses 26:253-257

32. McMahon DB, Shikata H, Breslin PA (2001) Are human taste thresholds similar on the right and left sides of the tongue? Chem Senses 26:875-883

33. O'Mahony M, Kingsley L, Harji A, Davies M (2006) What sensation signals the salt taste threshold. Chem Senses 2:177188

34. Seki T, Kawasaki Y, Tamura M, Tada M, Okai H (1990) Further study on the salty peptide ornithyl-â-alanine. Some effects of $\mathrm{pH}$ and additive ions on the saltiness. J Agric Food Chem 38:25-29

35. Tada M, Shinoda I, Okai H (1984) L-Ornithyltaurine, a new salty peptide. J Agric Food Chem 32:992-996

36. Huynhba T, Philippossian G (1990) L-Ornithyltaurine, a new salty peptide-comment. J Agric Food Chem 38:1993

37. Beidler LM (1954) A theory of taste stimulation. J Gen Physiol 38:133-139

38. Heck GL, Mierson S, DeSimone JA (1984) Salt taste transduction occurs through an amiloride-sensitive sodium transport pathway. Science 223:403-405

39. Kretz O, Barbry P, Bock R, Lindemann B (1999) Differential expression of RNA and protein of the three pore-forming subunits of the amiloride-sensitive epithelial sodium channel in taste buds of the rat. J Histochem Cytochem 47:51-64

40. Lin W, Finger TE, Rossier BC, Kinnamon SC (1999) Epithelial $\mathrm{Na}^{+}$channel subunits in rat taste cells: localization and regulation by aldosterone. J Comp Neurol 405:406-420

41. Hill DL, Formaker BK, White KS (1990) Perceptual characteristics of the amiloride-suppressed sodium chloride taste response in the rat. Behav Neurosci 104:734-741

42. Eylam S, Spector AC (2005) Taste discrimination between $\mathrm{NaCl}$ and $\mathrm{KCl}$ is disrupted by amiloride in inbred mice with amilorideinsensitive chorda tympani nerves. Am J Physiol Regul Integr Comp Physiol 288:R1361-R1368

43. Ossebaard CA, Polet IA, Smith DV (1997) Amiloride effects on taste quality: comparison of single and multiple response category procedures. Chem Senses 22:267-275

44. Ossebaard CA, Smith DV (1995) Effect of amiloride on the taste of $\mathrm{NaCl}, \mathrm{Na}$-gluconate and $\mathrm{KCl}$ in humans: implications for $\mathrm{Na}+$ receptor mechanisms. Chem Senses 20:37-46
45. Hummler E, Vallon V (2005) Lessons from mouse mutants of epithelial sodium channel and its regulatory proteins. J Am Soc Nephrol 16:3160-3166

46. Lyall V, Heck GL, Vinnikova AK, Ghosh S, Phan TH, Alam RI, Russell OF, Malik SA, Bigbee JW, DeSimone JA (2004) The mammalian amiloride-insensitive non-specific salt taste receptor is a vanilloid receptor-1 variant. J Physiol 558:147-159

47. Ruiz C, Gutknecht S, Delay E, Kinnamon S (2006) Detection of $\mathrm{NaCl}$ and $\mathrm{KCl}$ in TRPV1 knockout mice. Chem Senses 31:813820

48. Ye Q, Heck GL, DeSimone JA (1993) Voltage dependence of the rat chorda tympani response to $\mathrm{Na}+$ salts: implications for the functional organization of taste receptor cells. J Neurophysiol 70:167-178

49. James CE, Laing DG, Oram N (1997) A comparison of the ability of 8-9-year-old children and adults to detect taste stimuli. Physiol Behav 62:193-197

50. Arbisi PA, Billington CJ, Levine AS (1999) The effect of naltrexone on taste detection and recognition threshold. Appetite 32:241-249

51. Hellekant G, Danilova V (2005) Brazzein a small, sweet protein: discovery and physiological overview. Chem Senses 30(Suppl 1): i88-i89

52. Morris JA, Martenson R, Deibler G, Cagan RH (1973) Characterization of monellin, a protein that tastes sweet. J Biol Chem 248:534-539

53. van der Wel H, Loeve K (1972) Isolation and characterization of thaumatin I and II, the sweet-tasting proteins from Thaumatococcus daniellii Benth. Eur J Biochem 31:221-225

54. Shallenberger RS, Acree TE (1967) Molecular theory of sweet taste. Nature 216:480-482

55. Hoon MA, Adler E, Lindemeier J, Battey JF, Ryba NJ, Zuker CS (1999) Putative mammalian taste receptors: a class of tastespecific GPCRs with distinct topographic selectivity. Cell 96:541-551

56. Bachmanov AA, Li X, Reed DR, Ohmen JD, Li S, Chen Z, Tordoff MG, de Jong PJ, Wu C, West DB, Chatterjee A, Ross DA, Beauchamp GK (2001) Positional cloning of the mouse saccharin preference (Sac) locus. Chem Senses 26:925-933

57. Kitagawa M, Kusakabe Y, Miura H, Ninomiya Y, Hino A (2001) Molecular genetic identification of a candidate receptor gene for sweet taste. Biochem Biophys Res Commun 283:236-242

58. Max M, Shanker YG, Huang L, Rong M, Liu Z, Campagne F, Weinstein H, Damak S, Margolskee RF (2001) Tas1r3, encoding a new candidate taste receptor, is allelic to the sweet responsiveness locus Sac. Nat Genet 28:58-63

59. Montmayeur JP, Liberles SD, Matsunami H, Buck LB (2001) A candidate taste receptor gene near a sweet taste locus. Nat Neurosci 4:492-498

60. Nelson G, Hoon MA, Chandrashekar J, Zhang Y, Ryba NJ, Zuker CS (2001) Mammalian sweet taste receptors. Cell 106:381-390

61. Sainz E, Korley JN, Battey JF, Sullivan SL (2001) Identification of a novel member of the T1R family of putative taste receptors. J Neurochem 77:896-903

62. Li X, Staszewski L, Xu H, Durick K, Zoller M, Adler E (2002) Human receptors for sweet and umami taste. Proc Natl Acad Sci U S A 99:4692-4696

63. Zhao GQ, Zhang Y, Hoon MA, Chandrashekar J, Erlenbach I, Ryba NJ, Zuker CS (2003) The receptors for mammalian sweet and umami taste. Cell 115:255-266

64. Temussi P (2006) The history of sweet taste: not exactly a piece of cake. J Mol Recognit 19:188-199

65. Morini G, Bassoli A, Temussi PA (2005) From small sweeteners to sweet proteins: anatomy of the binding sites of the human T1R2_T1R3 receptor. J Med Chem 48:5520-5529 
66. Nie Y, Hobbs JR, Vigues S, Olson WJ, Conn GL, Munger SD (2006) Expression and purification of functional ligandbinding domains of T1R3 taste receptors. Chem Senses 31: 505-513

67. Jiang P, Ji Q, Liu Z, Snyder LA, Benard LM, Margolskee RF, Max $M(2004)$ The cysteine-rich region of T1R3 determines responses to intensely sweet proteins. J Biol Chem 279:45068-45075

68. Xu H, Staszewski L, Tang H, Adler E, Zoller M, Li X (2004) Different functional roles of T1R subunits in the heteromeric taste receptors. Proc Natl Acad Sci U S A 101:14258-14263

69. Jiang P, Cui M, Zhao B, Snyder LA, Benard LM, Osman R, Max M, Margolskee RF (2005) Identification of the cyclamate interaction site within the transmembrane domain of the human sweet taste receptor subunit T1R3. J Biol Chem 280:34296-34305

70. Stevens DR, Seifert R, Bufe B, Muller F, Kremmer E, Gauss R, Meyerhof W, Kaupp UB, Lindemann B (2001) Hyperpolarizationactivated channels HCN1 and HCN4 mediate responses to sour stimuli. Nature 413:631-635

71. Steiner JE, Glaser D, Hawilo ME, Berridge KC (2001) Comparative expression of hedonic impact: affective reactions to taste by human infants and other primates. Neurosci Biobehav Rev 25:53-74

72. Huffman MA (2003) Animal self-medication and ethno-medicine: exploration and exploitation of the medicinal properties of plants. Proc Nutr Soc 62:371-381

73. Adler E, Hoon MA, Mueller KL, Chandrashekar J, Ryba NJ, Zuker CS (2000) A novel family of mammalian taste receptors. Cell 100:693-702

74. Matsunami H, Montmayeur JP, Buck LB (2000) A family of candidate taste receptors in human and mouse. Nature 404:601-604

75. Wu SV, Chen MC, Rozengurt E (2005) Genomic organization, expression, and function of bitter taste receptors (T2R) in mouse and rat. Physiol Genomics 22:139-149

76. Go Y, Satta Y, Takenaka O, Takahata N (2005) Lineage-specific loss of function of bitter taste receptor genes in humans and nonhuman primates. Genetics 170:313-326

77. Chandrashekar J, Mueller KL, Hoon MA, Adler E, Feng L, Guo W, Zuker CS, Ryba NJ (2000) T2Rs function as bitter taste receptors. Cell 100:703-711

78. Mueller KL, Hoon MA, Erlenbach I, Chandrashekar J, Zuker CS, Ryba NJ (2005) The receptors and coding logic for bitter taste. Nature 434:225-229

79. Caicedo A, Kim KN, Roper SD (2002) Individual mouse taste cells respond to multiple chemical stimuli. J Physiol 544:501509

80. Behrens M, Foerster S, Staehler F, Raguse J-D, Meyerhof W (2006) Gustatory expression profiles of the full complement of human bitter taste receptor genes. Chem Senses 31:E72

81. Brockhoff A, Behrens M, Appendino G, Kuhn C, Meyerhof W (2006) Identification of agonist interaction sites in the human bitter taste receptor hTAS2R46. Chem Senses 31:E55

82. Lindemann B, Ogiwara Y, Ninomiya Y (2002) The discovery of umami. Chem Senses 27:843-844

83. Schlichtherle-Cerny H, Amado R (2002) Analysis of taste-active compounds in an enzymatic hydrolysate of deamidated wheat gluten. J Agric Food Chem 50:1515-1522

84. Tada M, Shinoda I, Okai H (1984) L-ornithyltaurine, a new salty peptide. J Agric Food Chem 32:992-996

85. Nakata T, Takahashi M, Nakatani M, Kuramitsu R, Tamura M, Okai H (1995) Role of basic and acidic fragments in delicious peptides (Lys-Gly-Asp-Glu-Glu-Ser-Leu-Ala) and the taste behavior of sodium and potassium-salts in acidic oligopeptides. Biosci Biotechnol Biochem 59:689-693

86. Rotzoll N, Dunkel A, Hofmann T (2006) Quantitative studies, taste reconstitution, and omission experiments on the key taste compounds in Morel mushrooms (Morchella deliciosa fr.). J Agric Food Chem 54:2705-2711
87. Faurion A (1991) Are umami taste receptor sites structurally related to glutamate CNS receptor sites? Physiol Behav 49:905-912

88. Chen PE, Wyllie DJ (2006) Pharmacological insights obtained from structure-function studies of ionotropic glutamate receptors. Br J Pharmacol 147:839-853

89. Stein E, Cox JA, Seeburg PH, Verdoorn TA (1992) Complex pharmacological properties of recombinant alpha-amino-3-hydroxy5-methyl-4-isoxazole propionate receptor subtypes. Mol Pharmacol 42:864-871

90. Delay ER, Hernandez NP, Bromley K, Margolskee RF (2006) Sucrose and monosodium glutamate taste thresholds and discrimination ability of T1R3 knockout mice. Chem Senses 31:351-357

91. Stapleton JR, Luellig M, Roper SD, Delay ER (2002) Discrimination between the tastes of sucrose and monosodium glutamate in rats. Chem Senses 27:375-382

92. Hong JH, Chung JW, Kim YK, Chung SC, Lee SW, Kho HS (2005) The relationship between PTC taster status and taste thresholds in young adults. Oral Surg Oral Med Oral Pathol Oral Radiol Endod 99:711-715

93. Chaudhari N, Landin AM, Roper SD (2000) A metabotropic glutamate receptor variant functions as a taste receptor. Nat Neurosci 3:113-119

94. Chaudhari N, Yang H, Lamp C, Delay E, Cartford C, Than T, Roper S (1996) The taste of monosodium glutamate: membrane receptors in taste buds. J Neurosci 16:3817-3826

95. Yang H, Wanner IB, Roper SD, Chaudhari N (1999) An optimized method for in situ hybridization with signal amplification that allows the detection of rare mRNAs. J Histochem Cytochem 47:431-446

96. Chaudhari N, Roper SD (1998) Molecular and physiological evidence for glutamate (umami) taste transduction via a $\mathrm{G}$ protein-coupled receptor. Ann NY Acad Sci 855:398-406

97. Nelson G, Chandrashekar J, Hoon MA, Feng L, Zhao G, Ryba NJ, Zuker CS (2002) An amino-acid taste receptor. Nature 416:199-202

98. Damak S, Rong M, Yasumatsu K, Kokrashvili Z, Varadarajan V, Zou S, Jiang P, Ninomiya Y, Margolskee RF (2003) Detection of sweet and umami taste in the absence of taste receptor T1r3. Science 301:850-853

99. Maruyama Y, Pereira E, Margolskee RF, Chaudhari N, Roper SD (2006) Umami responses in mouse taste cells indicate more than one receptor. J Neurosci 26:2227-2234

100. San-Gabriel AM, Uneyama H, Maekawa T, Yoshie S, Torii K (2006) The role of mGlur1 in rat taste and stomach tissue. Chem Senses 31:E90

101. Striem BJ, Pace U, Zehavi U, Naim M, Lancet D (1989) Sweet tastants stimulate adenylate cyclase coupled to GTP-binding protein in rat tongue membranes. Biochem $\mathrm{J}$ 260:121-126

102. Trubey KR, Culpepper S, Maruyama Y, Kinnamon SC, Chaudhari $\mathrm{N}$ (2006) Tastants evoke cAMP signal in taste buds that is independent of calcium signaling. Am J Physiol Cell Physiol 291: C237-C244

103. Avenet P, Hofmann F, Lindemann B (1988) Transduction in taste receptor cells requires cAMP-dependent protein kinase. Nature 331:351-354

104. Tonosaki K, Funakoshi M (1988) Cyclic nucleotides may mediate taste transduction. Nature 331:354-356

105. Krizhanovsky V, Agamy O, Naim M (2000) Sucrose-stimulated subsecond transient increase in cGMP level in rat intact circumvallate taste bud cells. Am J Physiol Cell Physiol 279: C120-C125

106. McLaughlin SK, McKinnon PJ, Margolskee RF (1992) Gustducin is a taste-cell-specific $G$ protein closely related to the transducins. Nature 357:563-569

107. Yan W, Sunavala G, Rosenzweig S, Dasso M, Brand JG, Spielman AI (2001) Bitter taste transduced by PLC-beta(2)- 
dependent rise in $\operatorname{IP}(3)$ and alpha-gustducin-dependent fall in cyclic nucleotides. Am J Physiol Cell Physiol 280:C742-C751

108. Wong GT, Gannon KS, Margolskee RF (1996) Transduction of bitter and sweet taste by gustducin. Nature 381:796-800

109. Danilova V, Damak S, Margolskee RF, Hellekant G (2006) Taste responses to sweet stimuli in alpha-gustducin knockout and wildtype mice. Chem Senses 31:573-580

110. Ruiz CJ, Wray K, Delay E, Margolskee RF, Kinnamon SC (2003) Behavioral evidence for a role of alpha-gustducin in glutamate taste. Chem Senses 28:573-579

111. Caicedo A, Pereira E, Margolskee RF, Roper SD (2003) Role of the G-protein subunit alpha-gustducin in taste cell responses to bitter stimuli. J Neurosci 23:9947-9952

112. Rossler P, Kroner C, Freitag J, Noe J, Breer H (1998) Identification of a phospholipase $\mathrm{C}$ beta subtype in rat taste cells. Eur J Cell Biol 77:253-261

113. Clapp TR, Stone LM, Margolskee RF, Kinnamon SC (2001) Immunocytochemical evidence for co-expression of Type III IP3 receptor with signaling components of bitter taste transduction. BMC Neurosci 2:6

114. Bernhardt SJ, Naim M, Zehavi U, Lindemann B (1996) Changes in IP3 and cytosolic $\mathrm{Ca} 2+$ in response to sugars and non-sugar sweeteners in transduction of sweet taste in the rat. J Physiol 490 (Pt 2):325-336

115. Spielman AI, Nagai H, Sunavala G, Dasso M, Breer H, Boekhoff I, Huque T, Whitney G, Brand JG (1996) Rapid kinetics of second messenger production in bitter taste. Am J Physiol 270: C926-C931

116. Akabas MH, Dodd J, al-Awqati Q (1988) A bitter substance induces a rise in intracellular calcium in a subpopulation of rat taste cells. Science 242:1047-1050

117. Caicedo A, Roper SD (2001) Taste receptor cells that discriminate between bitter stimuli. Science 291:1557-1560

118. DeFazio RA, Dvoryanchikov G, Maruyama Y, Kim JW, Pereira E, Roper SD, Chaudhari N (2006) Separate populations of receptor cells and presynaptic cells in mouse taste buds. J Neurosci 26:3971-3980

119. Clapp TR, Medler KF, Damak S, Margolskee RF, Kinnamon SC (2006) Mouse taste cells with G protein-coupled taste receptors lack voltage-gated calcium channels and SNAP-25. BMC Biol $4: 7$

120. Zhang Y, Hoon MA, Chandrashekar J, Mueller KL, Cook B, Wu D, Zuker CS, Ryba NJ (2003) Coding of sweet, bitter, and umami tastes: different receptor cells sharing similar signaling pathways. Cell 112:293-301

121. Dotson CD, Roper SD, Spector AC (2005) PLCbeta2-independent behavioral avoidance of prototypical bitter-tasting ligands. Chem Senses 30:593-600

122. Perez CA, Huang L, Rong M, Kozak JA, Preuss AK, Zhang H, Max M, Margolskee RF (2002) A transient receptor potential channel expressed in taste receptor cells. Nat Neurosci 5:1169-1176

123. Hofmann T, Chubanov V, Gudermann T, Montell C (2003) TRPM5 is a voltage-modulated and $\mathrm{Ca}(2+)$-activated monovalent selective cation channel. Curr Biol 13:1153-1158

124. Prawitt D, Monteilh-Zoller MK, Brixel L, Spangenberg C, Zabel B, Fleig A, Penner R (2003) TRPM5 is a transient Ca2+activated cation channel responding to rapid changes in $[\mathrm{Ca} 2+]$ i. Proc Natl Acad Sci U S A 100:15166-15171

125. Bezencon C, le Coutre J, Damak S (2007) Taste-signaling proteins are coexpressed in solitary intestinal epithelial cells. Chem Senses 32:41-49

126. Liu D, Liman ER (2003) Intracellular Ca2+and the phospholipid PIP2 regulate the taste transduction ion channel TRPM5. Proc Natl Acad Sci U S A 100:15160-15165

127. Damak S, Rong M, Yasumatsu K, Kokrashvili Z, Perez CA, Shigemura N, Yoshida R, Mosinger B Jr, Glendinning JI, Ninomiya
Y, Margolskee RF (2006) Trpm5 null mice respond to bitter, sweet, and umami compounds. Chem Senses 31:253-264

128. Perez CA, Margolskee RF, Kinnamon SC, Ogura T (2003) Making sense with TRP channels: store-operated calcium entry and the ion channel Trpm5 in taste receptor cells. Cell Calcium 33:541-549

129. Talavera K, Yasumatsu K, Voets T, Droogmans G, Shigemura N, Ninomiya Y, Margolskee RF, Nilius B (2005) Heat activation of TRPM5 underlies thermal sensitivity of sweet taste. Nature 438:1022-1025

130. Roper SD (1989) The cell biology of vertebrate taste receptors. Annu Rev Neurosci 12:329-353

131. Clapp TR, Yang R, Stoick CL, Kinnamon SC, Kinnamon JC (2004) Morphologic characterization of rat taste receptor cells that express components of the phospholipase $\mathrm{C}$ signaling pathway. J Comp Neurol 468:311-321

132. Yee CL, Yang R, Bottger B, Finger TE, Kinnamon JC (2001) "Type III" cells of rat taste buds: immunohistochemical and ultrastructural studies of neuron-specific enolase, protein gene product 9.5, and serotonin. J Comp Neurol 440:97-108

133. Finger TE, Danilova V, Barrows J, Bartel DL, Vigers AJ, Stone L, Hellekant G, Kinnamon SC (2005) ATP signaling is crucial for communication from taste buds to gustatory nerves. Science 310:1495-1499

134. Huang YJ, Maruyama Y, Lu KS, Pereira E, Plonsky I, Baur JE, Wu D, Roper SD (2005) Mouse taste buds use serotonin as a neurotransmitter. J Neurosci 25:843-847

135. Huang YJ, Maruyama Y, Pereira E, Roper SD (2006) Cell-to-cell communication in taste buds: The role of ATP and 5HT. Chem Senses 31:A23

136. Nagai T, Kim DJ, Delay RJ, Roper SD (1996) Neuromodulation of transduction and signal processing in the end organs of taste. Chem Senses 21:353-365

137. Kaya N, Shen T, Lu SG, Zhao FL, Herness S (2004) A paracrine signaling role for serotonin in rat taste buds: expression and localization of serotonin receptor subtypes. Am J Physiol Regul Integr Comp Physiol 286:R649-R658

138. Delay RJ, Kinnamon SC, Roper SD (1997) Serotonin modulates voltage-dependent calcium current in Necturus taste cells. J Neurophysiol 77:2515-2524

139. Herness MS, Chen Y (2000) Serotonergic agonists inhibit calcium-activated potassium and voltage-dependent sodium currents in rat taste receptor cells. J Membr Biol 173:127-138

140. Heath TP, Melichar JK, Nutt DJ, Donaldson LF (2006) Human taste thresholds are modulated by serotonin and noradrenaline. J Neurosci 26:12664-12671

141. Gilbertson TA, Boughter JD Jr, Zhang H, Smith DV (2001) Distribution of gustatory sensitivities in rat taste cells: whole-cell responses to apical chemical stimulation. J Neurosci 21:49314941

142. Yoshida R, Shigemura N, Sanematsu K, Yasumatsu K, Ishizuka S, Ninomiya Y (2006) Taste responsiveness of fungiform taste cells with action potentials. J Neurophysiol

143. Pumplin DW, Yu C, Smith DV (1997) Light and dark cells of rat vallate taste buds are morphologically distinct cell types. J Comp Neurol 378:389-410

144. Bartel DL, Sullivan SL, Lavoie EG, Sevigny J, Finger TE (2006) Nucleoside triphosphate diphosphohydrolase-2 is the ecto-ATPase of type I cells in taste buds. J Comp Neurol 497:1-12

145. Smith DV, St John SJ (1999) Neural coding of gustatory information. Curr Opin Neurobiol 9:427-435

146. Katz DB, Simon SA, Nicolelis MA (2001) Dynamic and multimodal responses of gustatory cortical neurons in awake rats. J Neurosci 21:4478-4489 
147. Hallock RM, Di Lorenzo PM (2006) Temporal coding in the gustatory system. Neurosci Biobehav Rev 30:1145-1160

148. Bufe B, Hofmann T, Krautwurst D, Raguse JD, Meyerhof W (2002) The human TAS2R16 receptor mediates bitter taste in response to beta-glucopyranosides. Nat Genet 32: 397-401

149. Bufe B, Bresliin PA, Kuhn C, Reed DR, Tharp CD, Slack JP, Kim UK, Drayna D, Meyerhof W (2005) The molecular basis of individual differences in phenylthiocarbamide and propylthiouracil bitterness perception. Curr Biol 15:322-327

150. Kuhn C, Bufe B, Winnig M, Hofmann T, Frank O, Behrens M, Lewtschenko T, Slack JP, Ward CD, Meyerhof W (2004) Bitter taste receptors for saccharin and acesulfame K. J Neurosci 24:10260-10265

151. Huan Y-J, Maruyama Y, Dvoryanchikov G, Pereira E, Chaudhari N, Roper SD (2007) The role of pannexin 1 hemichannels in ATP release and cell-cell communication in mouse taste buds. Proc Natl Acad Sci USA 104, published PNAS online Mar 26, 2007

152. Romanov RA, Rogachevskaja OA, Bystrova MF, Jiang P, Margolskee RF, Kolesnikov SS (2007) Afferent neurotransmission mediated by hemichannels in mammalian taste cells. EMBO J 26:657-667 